Review

\title{
Some Aspects of Modern Drones
}

\author{
Relly Victoria Virgil Petrescu \\ ARoTMM-IFToMM, Bucharest Polytechnic University, Bucharest, (CE) Romania
}

Article history

Received: 05-05-2021

Revised: 16-05-2021

Accepted: 20-05-2021

Email: rvvpetrescu@gmail.com

\begin{abstract}
Today drones have become so important that everyday life can no longer be conceived without them. The paper wishes to present some essential aspects regarding modern drones, their capabilities and their uses. Drones and minnies drones have penetrated deep into technology, industry, agriculture, the military and police area, security services, security and control, aerial surveillance, signaling, aerial filming, cartography, danger and fire signaling in a timely manner, surveillance missions, security, defense and attack. The major advantages of drones compared to conventional aircraft are the following: A much lower fuel consumption and a much lower polarization of the environment, sometimes the pole does not even exist the drones being electrically moved; much lower design, manufacturing, maintenance and operation prices. They do not require pilots, they are generally small and the manufacturing costs and materials are much reduced; in case of collisions they are very resistant, accidents with them being rare and without tragic consequences; they can operate various things without a pilot, without costs, without risks, with superior results to those of classic aviation. A simple way to reduce the consumption of raw materials needed by industries is the very economy of materials used in industries and the start must be made even with heavy industries and car manufacturers and primarily those in aviation and aerospace. With drones, the consumption of materials is extraordinary compared to the materials stored in old, classic, huge ships. Of course, large public aircraft are still needed for public passenger transport, which, no matter how redesigned, will still consume a lot of materials and energy, but for other daily air operations, drones will be able to successfully intervene in place of large and heavy ships. These areas will see huge savings in materials, not to mention the very low costs of people who will be replaced by robots, vending machines, cameras, low fuel consumption and the reduction and even elimination of massive pollution that was done by a massive use of large aircraft for any minor operations requiring flights. The drones come to usefully and efficiently complete large and important areas of flight, difficult and meticulous operations, the drones clearly having increased capabilities and much higher penetration.
\end{abstract}

Keywords: Drones, Modern Drones, Drone Capabilities

\section{Introduction}

The major advantages of drones compared to conventional aircraft are the following: A much lower fuel consumption and a much lower polarization of the environment, sometimes the pole does not even exist the drones being electrically moved; much lower design, manufacturing, maintenance and operation prices. They do not require pilots, they are generally small and the manufacturing costs and materials are much reduced; in case of collisions they are very resistant, accidents with them being rare and without tragic consequences; they can operate various things without a pilot, without costs, without risks, with superior results to those of classic aviation.

Drones and minnies drones have penetrated deep into technology, industry, agriculture, the military and police area, security services, security and control, aerial surveillance, signaling, aerial filming, cartography, danger and fire signaling in a timely manner, surveillance missions, security, defense and attack. 
Key specifications of a DJI Mavic Mini Fly More Combo mini drone, which sells well on the market: Ultralight, weighing only $249 \mathrm{~g}$, Maximum flight time: 30 min, HD video transmission up to $2 \mathrm{~km}$, Vision Sensor and GPS Precise Hover, 3-axis gimbal, 2.7K QHD camera resolution, Simplified recording and editing, Sensor range 0.5 to $10.0 \mathrm{~m}$, Price: 380 Euro (Fig. 1).

Unmanned aerial vehicles - or drones - are a fast-growing aviation sector with significant potential to create new jobs and growth in the European Union. That is why the EU has adopted a regulation aimed at the safe integration of remotely piloted drones into European airspace.

The Regulation establishes a set of common rules for civil aviation safety and a revised mandate for the European Aviation Safety Agency (EASA). The new EASA Regulation replaces the 2008 legislative framework.

On 26 June 2018, the Council adopted the new proportionate and risk-based rules, which will allow the EU aviation sector to grow and become more competitive.

For example, the new rules also apply to the registration threshold for drone operators: They should be registered if their drones can transfer the kinetic energy of more than 80 joules to the impact on a person.

Although some drones are as heavy and fast as an airplane, they can also take the form of very small electrical "toys" that are widely available to consumers.

After 2008, smaller drones created regulatory problems for the EU, whose competencies were limited to unmanned aerial vehicles over $150 \mathrm{~kg}$.

Lighter drones were subject only to different and fragmented national safety rules at the EU level. Moreover, certain essential security measures were not applied consistently.

The reform of aviation rules was also necessary because EU air traffic is expected to increase by $50 \%$ over the next 20 years.

The European Commission estimates that by 2035, the European drone sector:

- will directly provide jobs for over 100,000 people

- will have an economic impact of over EUR 10 billion per year, mainly in the field of services

As the use of drones expands, so will the need to find a balance between their advantages and the problems they generate. For example, unmanned aerial vehicles can provide added value when used for data collection and interpretation in different sectors of the economy. But drones can also create problems in terms of data protection, privacy, noise and $\mathrm{CO}_{2}$ emissions.

On 12 March 2019, the European Commission adopted rules at the EU level to establish technical requirements for drones.

In accordance with the EFSA Regulation, the new rules establish the basic principles for ensuring the security, safety and protection of privacy, as well as the protection of personal data.

They also aim to reduce bureaucracy and encourage innovation.

The regulation also removes certain rules that could inhibit entrepreneurship. It is expected to generate legal certainty for a sector comprising a large number of small and medium-sized enterprises and start-ups.

In addition, the regulation introduces a safety approach based on risks and performance.

The drones come to usefully and efficiently complete large and important areas of flight, difficult and meticulous operations, the drones clearly having increased capabilities and much higher penetration.

This means that the regulation recognizes the various risks that arise in different sectors of civil aviation.

For example, helicopters or light recreational aircraft are subject to simpler and cheaper approval procedures than commercial aviation (Rulkov et al., 2016; Agarwala, 2016; Babayemi, 2016; Catana et al., 2017; Cican et al., 2018, 2019, 2020; Deaconu et al., 2020, Deaconu and Cican, 2018; Gusti and Semin, 2016; Mohamed et al., 2016; Wessels and Raad, 2016; Rajput et al., 2016; Rea and Ottaviano, 2016; Zurfi and Zhang, 2016a; 2016b; Popa et al., 2019; Zheng and Li 2016; Buonomano et al., 2016a; 2016b; Faizal et al., 2016; Ascione et al., 2016; Elmeddahi et al., 2016; Calise et al., 2016; Morse et al., 2016; Abouobaida, 2016; Rohit and Dixit, 2016; Kazakov et al., 2016; Alwetaishi, 2016; Riccio et al., 2016a; 2016b; Iqbal, 2016; Hasan and El-Naas, 2016; Al-Hasan and AlGhamdi, 2016; Jiang et al., 2016; Sepúlveda, 2016; Martins et al., 2016; Pisello et al., 2016; Jarahi, 2016; Mondal et al., 2016; Mansour, 2016; Al Qadi et al., 2016b; Campo et al., 2016; Samantaray et al., 2016; Malomar et al., 2016; Rich and Badar, 2016; Hirun, 2016; Bucinell, 2016; Nabilou, 2016; Barone et al., 2016; Chisari and Bedon, 2016; Bedon and Louter, 2016; Dos Santos and Bedon, 2016; Minghini et al., 2016; Bedon, 2016; Jafari et al., 2016; Chiozzi et al., 2016; Orlando and Benvenuti, 2016; Wang and Yagi, 2016; Obaiys et al., 2016; Ahmed et al., 2016; Jauhari et al., 2016; Syahrullah and Sinaga, 2016; Shanmugam, 2016; Jaber and Bicker, 2016; Wang et al., 2016; Moubarek and Gharsallah, 2016; Amani, 2016; Shruti, 2016; Pérez-de León et al., 2016; Mohseni and Tsavdaridis, 2016; Abu-Lebdeh et al., 2016; Serebrennikov et al., 2016; Budak et al., 2016; Augustine et al., 2016; Jarahi and Seifilaleh, 2016; Nabilou et al., 2016; You et al., 2016; AL Qadi et al., 2016a; Rama et al., 2016; Sallami et al., 2016; Huang et al., 2016; Ali et al., 2016; Kamble and Kumar, 2016; Saikia and Karak, 2016; Zeferino et al., 2016; Pravettoni et al., 2016; Bedon and Amadio, 2016; Chen and $\mathrm{Xu}, 2016$; Mavukkandy et al., 2016; Yeargin et al., 2016; Madani and Dababneh, 2016; Alhasanat et al., 2016; Elliott et al., 2016; Suarez et al., 2016; Kuli et al., 2016; Waters et al., 
2016; Montgomery et al., 2016; Lamarre et al., 2016; Petrescu, 2012b; Aversa et al., 2017a; 2017b; 2016a; 2016b; 2016c; 2016d; 2016e; 2016f; 2016g; 2016h; 2016i; 2016j; 2016k; 2016l; 2016m; 2016n; 2016o; Petrescu and Petrescu, 2016; 2015a; 2015b; 2015c; 2015d; 2015e; 2014a; 2014b; 2014c; 2014d; 2014e; 2014f; 2014g; 2013; 2005a; 2005b; 2005c; 2005d; Petrescu, 2018; 2015a; 2015b; Petrescu et al., 2016; 2017a; 2017b; 2017c; 2018a; 2018b; 2018c; 2018d; Petrescu and Calautit, 2016a; 2016b; Daud et al., 2008; Taher et al., 2008; Zulkifli et al., 2008; Pourmahmoud, 2008; Pannirselvam et al., 2008; Ng et al., 2008; ElTous, 2008; Akhesmeh et al., 2008; Nachiengtai et al., 2008; Moezi et al., 2008; Boucetta, 2008; Darabi et al., 2008; Semin, 2008; Al-Abbas, 2009; Abdullah et al., 2009; Abu-Ein, 2009; Opafunso et al., 2009; Semin et al., 2009a; 2009b; 2009c; Zulkifli et al., 2009; Ab-Rahman et al., 2009; Abdullah and Halim, 2009; Zotos and Costopoulos, 2009; Feraga et al., 2009; Bakar et al., 2009; Cardu et al., 2009; Bolonkin, 2009a; 2009b; Nandhakumar et al., 2009; Odeh et al., 2009; Lubis et al., 2009; Fathallah and Bakar, 2009; Marghany and Hashim, 2009; Kwon et al., 2010; Aly and Abuelnasr, 2010; Farahani et al., 2010; Ahmed et al., 2010; Kunanoppadon, 2010; Helmy and El-Taweel, 2010; Qutbodin, 2010; Pattanasethanon, 2010; Fen et al., 2011; Thongwan et al., 2011; Theansuwan et al., 2011; Al Smadi, 2011; Tourab et al., 2011; Raptis et al., 2011; Momani et al., 2011; Ismail et al., 2011; Anizan et al., 2011; Tsolakis and Raptis, 2011; Abdullah et al., 2011; Kechiche et al., 2011; Ho et al., 2011; Rajbhandari et al., 2011; Aleksic and Lovric, 2011; Kaewnai and Wongwises, 2011; Darwazeh and Ahmed, 2011; Ebrahim et al., 2012; Abdelkrim et al., 2012; Mohan et al., 2012; Abam et al., 2012; Hassan et al., 2012; Jalil and Sampe, 2013; Jaoude and El-Tawil, 2013; Ali and Shumaker, 2013; Sandu et al., 2020; Zhao, 2013; El-Labban et al., 2013; Djalel et al., 2013; Nahas and Kozaitis, 2014).

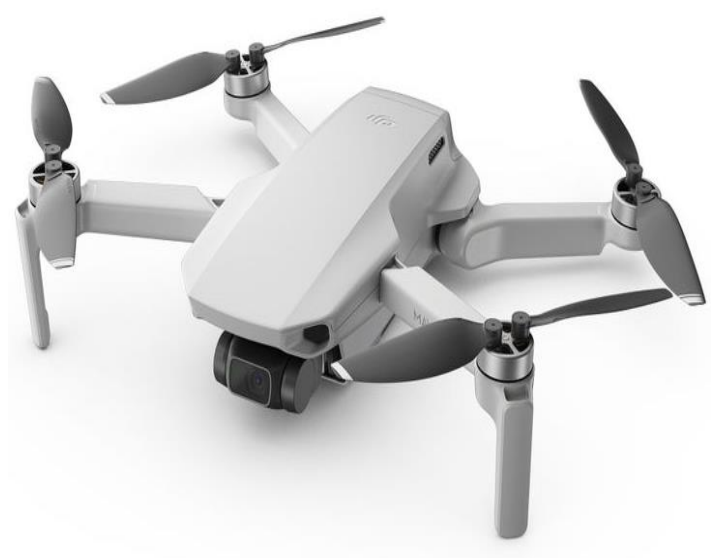

Fig. 1: DJI mavic mini fly more combo mini drone

\section{Materials and Methods}

A major problem that still plagues our planet is the massive need for metals, heavy, light, special, rare, precious, alloys, which are increasingly needed, while planetary surface resources are increasingly limited.

Given the declining planetary resources and increasing their consumption, at least some of them could be brought from outside the planet, such as metals or diamonds, so as not we try to find them or supplements in the depths of the earth, so as not to disturb the balance of our planet.

The attempt to dig deeper into the earth's crust, embarking on a journey to the depths, in search of new metals and other deposits, has failed, being even more difficult today than a journey through outer space, an underwater, one in space, or one to a nano size world. For this reason, scientists have recently remembered about an older idea of trying to bring metals from outer space, where they exist in massive quantities, especially since some sources (asteroids) are quite close and today we already have very fast ships capable to realize of such a brave and daring enterprise.

Astronomers created icon-like symbols for the first fifteen asteroids to be discovered, as a type of shorthand notation consistent with older notation for the classical planets. Psyche was given an iconic symbol, as were a few other asteroids discovered after 16 Psyche. The symbol 16 Psyche, a semicircle topped by a star, represents a butterfly's wing, a symbol of the soul (psyche is the Greek word for "soul") and a star.

However, the iconic symbols for all asteroids were superseded and Psyche's symbol never came into use. With more than a dozen asteroids discovered, remembering all their individual emblems became increasingly unwieldy and in 1851, German astronomer J.F. Encke suggested using a circled number instead. The first new asteroid that was designated in 1852 using this new scheme was 16 Psyche when American astronomer James Ferguson published his observations.

Psyche (Fig. 2), is massive enough that its gravitational perturbations on other asteroids can be observed, which enables a mass measurement. The values for the mass of $3.38 \pm 0.28 \times 10^{-11} \mathrm{M}_{\odot}$ and the density of $6.98 \pm 0.58 \mathrm{~g} / \mathrm{cm}^{3}$ obtained from a 2002 analysis by Kuzmanoski and Kovačević, of a close encounter with asteroid (13206) 1997 GC22. The new, high-density estimate suggests that 16 Psyche must be composed mostly of metals. As of 2019, the best mass estimate is $(2.41 \pm 0.32) \times 10^{19} \mathrm{~kg}$, with a derived bulk density of $(3.99 \pm 0.26) \mathrm{g} / \mathrm{cm}^{3}$.

The first size estimate of Psyche came from IRAS thermal infrared emission observations. They showed that it had a diameter of about $253 \mathrm{~km}$, although it was likely an overestimate as Psyche was viewed pole-on at that time. Light curve analysis indicates Psyche appears somewhat irregular in shape. There is a pronounced mass deficit near the equator at about $90^{\circ}$ longitude comparable 
to the Rheasilvia basin on Vesta. There are also two additional smaller $(50-70 \mathrm{~km}$ in diameter) crater-like depressions near the south pole. Psyche's north pole points towards the ecliptic coordinates $\beta=28^{\circ}, \lambda=-6^{\circ}$, with a $4^{\circ}$ uncertainty. This gives an axial tilt of $95^{\circ}$.

Observations of two multi-chord stellar occultations of 2010 and 2014 allow the matching of light curve inversions DAMIT model 1806 that give an equivalentvolume mean diameter of $216 \pm 12 \mathrm{~km}$ and an equivalent surface means the diameter of $227 \pm 13 \mathrm{~km}$. The density of Psyche derived from these estimates $-3.7 \pm 0.6 \mathrm{~g} / \mathrm{cm}^{3}-$ is consistent with that of other metallic asteroids.

Observations of Psyche with Very Large Telescope's adaptive optics SPHERE imager revealed two large craters, which were informally named Meroe and Panthia, after the twin witches in the Roman novel Metamorphoses by Apuleius.

NASA is going to build a robot, called "Psyche", which will have the mission to explore an asteroid in the main asteroid belt between Mars and Jupiter. The asteroid "16 Psyche" has a diameter of 226 kilometers and is made of metals such as iron, nickel and gold. The metals that make up this unique asteroid could be worth more than $\$ 10$ trillion.

Located in the main asteroid belt between Mars and Jupiter, "16 Psyche" is rich in metals including iron, nickel and the core is made of gold.

Researchers believe that the asteroid's core is similar to that of Earth, which means it could be the heart of a dead planet that has lost its rocky outer layers or suffered violent collisions. The metals that make up this asteroid could be worth $\$ 10$ trillion.

The "Psyche" robot is scheduled to be launched in 2022, using a SpaceX Falcon Heavy rocket. A year later, in 2023, it will pass over the planet Mars and only in 2026 will it orbit the asteroid "16 Psyche".

The "Psyche" mission is part of NASA's low-cost robotic space mission program.

A simple way to reduce the consumption of raw materials needed by industries is the very economy of materials used in industries and the start must be made even with heavy industries and car manufacturers and primarily those in aviation and aerospace. With drones, the consumption of materials is extraordinary compared to the materials stored in old, classic, huge ships. Of course, large public aircraft are still needed for public passenger transport, which, no matter how redesigned, will still consume a lot of materials and energy, but for other daily air operations, drones will be able to successfully intervene in place of large and heavy ships. These areas will see huge savings in materials, not to mention the very low costs of people who will be replaced by robots, vending machines, cameras, low fuel consumption and the reduction and even elimination of massive pollution that was done by a massive use of large aircraft for any minor operations requiring flights. The drones come to usefully and efficiently complete large and important areas of flight, difficult and meticulous operations, the drones clearly having increased capabilities and much higher penetration.

They are one of the smartest and hardest flyings. It can fly hundreds of miles a day, doing things you couldn't even think of. Driven by restlessness and technology, these guys convinced the restless travelers to find, literally, the needle in the hay wagon. With wings of four meters, a speed of $85 \mathrm{~km} / \mathrm{h}$ and eagle eyes, our drones detect in flight the imminent danger, theft, energy loss and even vegetation that could climb on your house. Everything is transmitted on video cameras. The smart drones are created in Romania, with the help of European funds.

The project that turned a smart dream into reality was born from the idea of some engineers to fly over the airspace, in order to reduce costs. Then this idea went further. Today, drones not only save a lot of money, but also save time, energy and lives. Due to its exceptional performance, the invention with a Romanian patent could be sold all over the globe. Equipped with the most intelligent video and thermal imaging equipment, the devices represent the future, including in the study of lands that are difficult to access or even inaccessible until today (Fig. 3).

The SMIATIC project - "Advanced monitoring and inspection system, air and ground infrastructure" was implemented by Energy \& Eco Concept SRL and benefited from funding of 1.5 million euros and the support of the Polytechnic University of Bucharest. The pilot project was developed in partnership with Transelectrica, to verify electricity transmission networks. The company has over $17,000 \mathrm{~km}$ of the network throughout the country. Smart drones can solve many of today's problems in areas inaccessible to employees. For example, on a route of hundreds of hectares, where each pillar of electricity should be checked separately, their work would be tens of times harder and hundreds of times more expensive than the intervention of these devices.

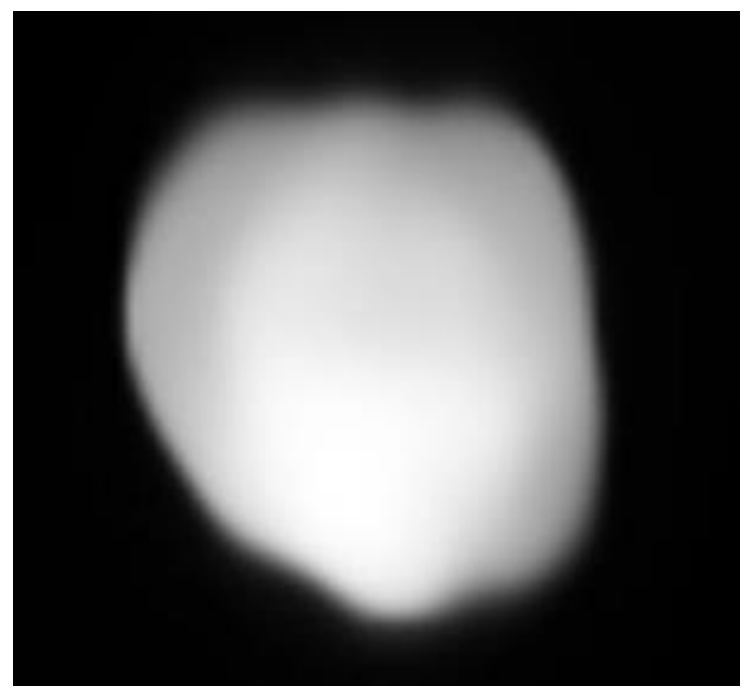

Fig. 2: 16 Psyche imaged by the Very Large Telescope's adaptive optics SPHERE imager 
SMIATIC - Advanced air and ground monitoring and inspection system for critical infrastructures were funded by the Operational Program Competitiveness (POC) 2014-2020. The project was implemented, with great success, in the period 2016-2018.

The latest technology, created in Romania, is friendly and environmentally friendly: It does not pollute and contributes to reducing pollution, wherever it discovers it.

The project aimed to increase the efficiency of covering monitored and inspected areas at lower prices than traditional air or ground solutions operated by personnel and to increase the availability and redundancy of the system, through intelligent mission management and by increasing air presence time. of drones. Drone autonomy will be maximized through innovative energy resource management solutions.

The drone can be defined as an unmanned aircraft capable of autonomous navigation, without being controlled from the outside, using the autopilot, or which can be controlled by a remote control device. In addition, the drone can be controlled via WI-FI, smartphones, or tablets equipped with Android or iOS.

Drones come in a wide range of shapes and sizes. In terms of use, drones are divided into the following categories: -Unmanned Aerial Vehicle (UAV). Unmanned Surface Vehicle (USV). - Unmanned Underwater Vehicle (UUV). - Unmanned Ground Vehicle (UGV). - Pseudo High Altitude Satellites (HAPS).

The most popular and most used are Unmanned Aerial Vehicles (UAVs). Regardless of its use, the unmanned aerial vehicle runs on batteries or energy produced by their own photovoltaic cells. These types of drones are equipped with electric motors, one for each propeller. Drones equipped with internal combustion engines are less used in applications than drones with electric motors. Depending on the number of engines and their power, drones can be classified into three copters, quadcopters, hexacopters, octocopters, etc.

The three copters is a drone-like helicopter, which has three rotors and propulsion units with servomotors, Rotors/propellers. A quadcopter is stabilized using different technologies, but the main stabilizers are gyroscopes. Hexacopters are remote-controlled flight devices that have six rotors/propellers. The hexacopter is a type of drone with advanced technology characterized by good maneuverability. Octocopters have eight engines and propellers. These drones had high speeds, safety and high stability and can fly at extreme altitudes, even in adverse weather conditions.

The first drone was designed by Nikola Tesla in 1898 (Fig. 4).

Later, this model was improved by the engineer Charles F. Kettering, who attached an electronic device to the model, by which the drone modifies its propellers to fall into enemy positions. A more similar model to the one used today was the QAM-34, created in 1948 and first tested in 1951. Drone technology is developing rapidly. Motorized devices are becoming increasingly complex, with multiple functions, but much easier to control. Regardless of the type of drone, their most important characteristics are, in general, the following: -Maximum operating distance; -flight/journey time; -flight/travel speed; of sensors; -board GPS system; operating frequency; -weight.

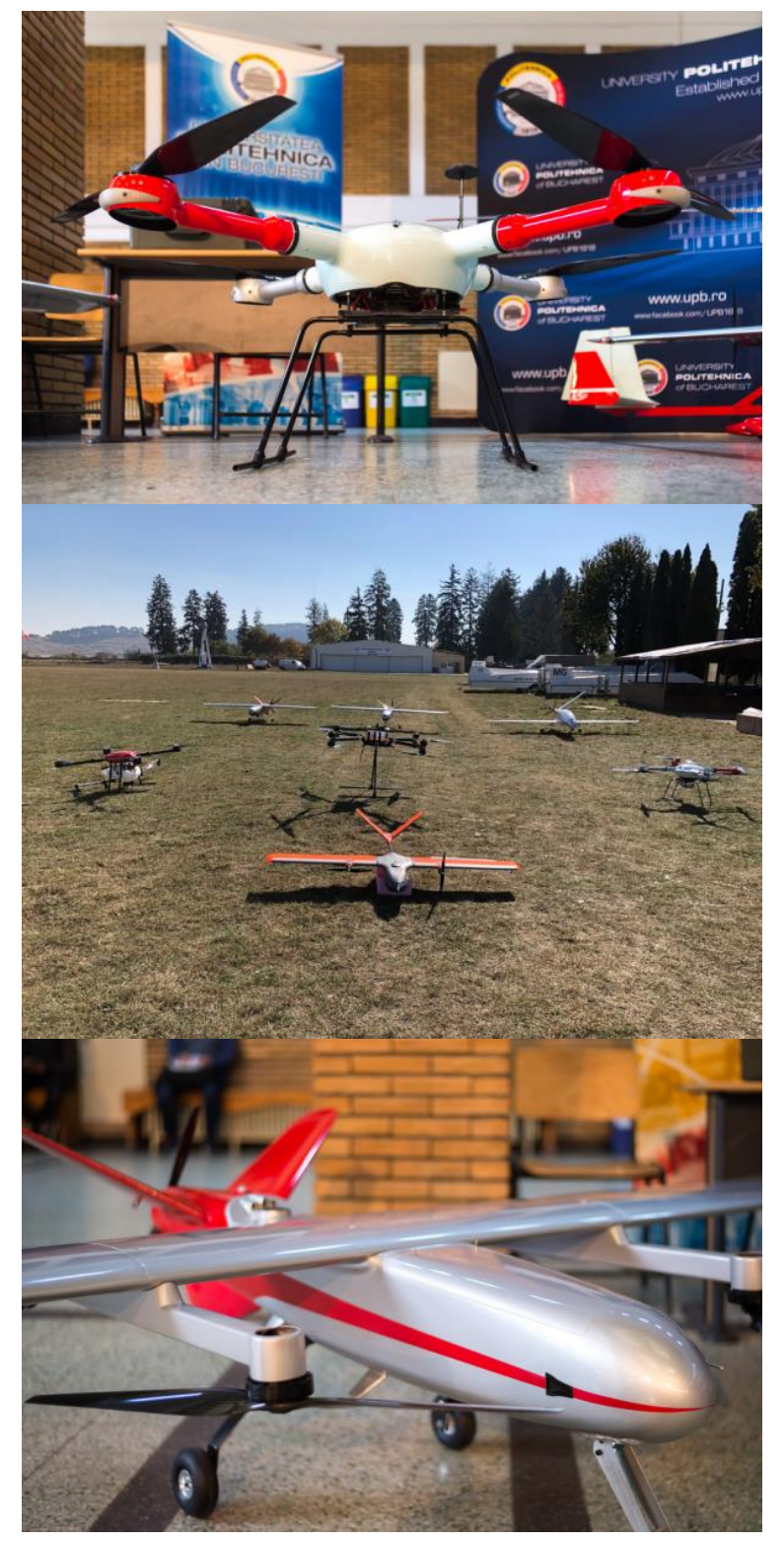

Fig. 3: The SMIATIC project - "Advanced monitoring and inspection system, air and ground infrastructure" was implemented by Energy and Eco Concept SRL and benefited from funding of 1.5 million euros and the support of the Polytechnic University of Bucharest 
The year 2011 brought with it one of the most important events in the fight against terrorism - the capture by Osama Bin Laden's SEAL troops in the Pakistani city of Abbottabad (Fig. 5). The story of these unmanned aircraft, as secret as they are sophisticated, begins in the $2000 \mathrm{~s}$ and $2001 \mathrm{~s}$, when the US Air Force reconfigured a Hellfire anti-tank missile to fit a Predator HQ-1 surveillance drone. The program to create these lethal weapons was boosted by the George W. Bush Administration in order to reduce the military budget for conventional warfare and the withdrawal of ground troops. Thus, through the precise blows of the drones, the Pentagon had the opportunity to avoid collateral casualties in the war on terror. The first known drone attack took place in November 2001, killing Taliban commander Mohammed Atef in Afghanistan.

The new "Obama doctrine" focuses on multilateralism, drone strikes and a reduced military presence in Libya, Pakistan and Yemen. According to government figures from 2006 to date, the number of AlQaeda militants killed by drones has reached 2,000 (along with collateral civilian casualties). Thus, after numerous attacks on the tribal area of Waziristan (Pakistan) resulting in casualties among the locals, the attitude of Pakistanis towards the US becomes ambivalent. In reality, these situations are caused by errors and drone strikes produce fewer casualties than military interventions or less selective bombing.

As the fighting continues, some experts believe that this "secret war" must be made transparent, at least to the extent that tensions between Pakistan and the United States have strained. Especially since American troops will need military assistance from Islamabad to secure the withdrawal corridor from Afghanistan by 2014. Few people know about the real situation in the tribal areas on the border between Afghanistan and Pakistan, where entire regions have become theaters of war and AlQuaeda formed true autonomous networks that could freely cross insecure borders. This war of attrition by drones was probably inevitable for the destruction of the terrorist stronghold. However, the Islamabad government exercises partial control over its own tribal regions and its army continues to house Taliban fighters, who can easily cross the Afghan-Pakistani border to help "Muslim brothers" in their fight against Western "pagans." Pakistani officials, while criticizing the drone attacks, in particular, agree that they are helping the army fight extremists. The US has expanded its drone base from Afghanistan, Pakistan, Yemen and Somalia to Ethiopia, Djibouti, Seychelles and, now, to Iran, which is under reconnaissance and surveillance missions. The year 2011 ended with the Pentagon's request to Tehran to return the "top secret" RQ-170 Sentinel drone, which crashed on December 4 in Iran. So far, the total fleet of UAVs is 7000 units, of which the United States has lost more than 50 units and since July 2010, 79 accidents have been identified due to several reasons: Bad weather, error of connection, or operation and "human error".

The CIA, which has become more like a paramilitary agency and not an intelligence agency, is in charge of operating most drones and in Yemen, the main executive authority for some drone strikes is the Pentagon. We need to understand that most of the time drones are used to gather information. For example, the old U-2 crews during the Cold War have been replaced by the Global Hawk drone, which can send detailed images of the Earth and has the ability to detect chemical, biological, or nuclear weapons. Moreover, it was possible to create an advanced prototype - Gorgon Stare - that will be able to "look at an entire city". At the same time, the number of American multi-role drones - which can hit and spy - is expected to increase fourfold. The good part is that unlike the new F-16 fighter, which requires around $\$ 55$ million to operate, UAVs are less expensive (a Global Hawk requires 15 million), although expensive technology and crashes can make up the difference.

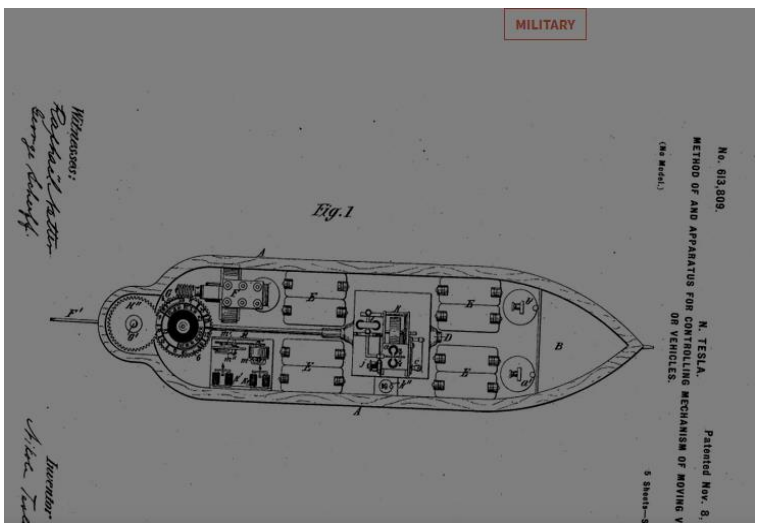

Fig. 4: The first drone was designed by Nikola Tesla in 1898

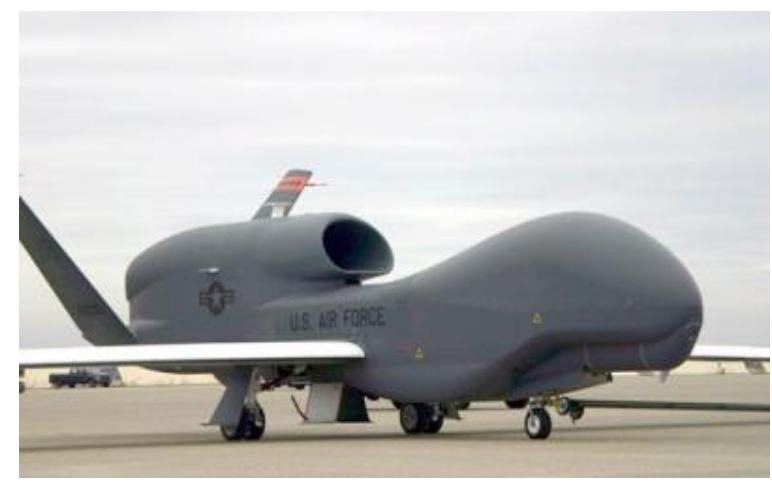

Fig. 5: Military drone frequently used by the US military 
Another challenge to international security is the global proliferation of drones. Although it may facilitate the security of certain areas of the state, military security relations may fall into well-understood patterns of action and reaction. Currently, the number of states that have access to such capabilities has reached 70, developing around 680 research programs. China already has 25 types of systems under development and Ahmadinejad said Iran already has its own drone model - "Ambassador of Death" (!)

The technology has been expanded from the military to the civilian sector. US police forces purchase models of drones to monitor the border or risk areas.

In addition to killing al-Qaeda militants, the drone war bears the imprint of a psychological war: In Waziristan, their humming can be heard throughout the day, with the psychological effect of widespread panic among both Islamist militants and the civilian population. Militants are aware of the effectiveness of drones and therefore prefer not to meet in large groups, not even in mosques and spend their nights outdoors. The feeling of insecurity is leading the Taliban to take more drastic measures to communicate within the network and is distrustful of any journalist.

In any case, drones have become a reality of a secret war waged by Washington and it is far from over. The escalation of this asymmetric war will certainly lead to the development of countermeasures to UAV technology.

The drones will be able to be used successfully, efficiently and without problems in the rapid and automatic planting of trees, in order to mass reforestation, fast, cheap and quality, obviously in order to restore the climate on our old planet.

Mapping some agricultural areas can be done most efficiently with the help of drones, safer, cheaper, more successful and much closer than from distant and very expensive satellites.

We all know humans can't fly. Our bones are far too dense and flapping our arms does not produce adequate lift to overcome the pull of gravity, but luckily we can use technology to give us the experience of flying. I'm not talking about flying in airplanes though, or a hang glider, or jumping out of airplanes, or using a zip line. We can actually use multirotor aircraft to give us the impression of flying using a technology called FPV. I think "flying" with an FPV-equipped multirotor is even better than flying with any of the aforementioned technologies though because multi-rotors are infinitely more agile. Flying with FPV is more like being a bird and less like being thrown through the air. It is an amazing and very fun, technology.

This Instructable will show you how to build what I would categorize as a high-performance FPV quadcopter that can be used to take amazing aerial photos and videos. Could be using a top-of-the-line flight controller (the DJI Naza M Lite) and an excellent FPV system from Fat Shark, with the PilotHD camera for both recording video and delivering the FPV feed. Could also be using high- quality motors and ESCs designed specifically for use in multi-rotors. Finally, we will be using a premium-quality Spektrum radio system. More about the parts list for this project can be found in the next step.

\section{Results}

I also stated that drones can penetrate other planets, being the most penetrating and economical spies and scouts, with long life and low resource consumption, without major risks and without people anyway.

The first important step of the Mars 2020 mission took place on February 18, when Perseverance (Mars Exploration Rover) reached the ground of the Red Planet, successfully landing in Jezer Crater, the place selected by NASA team members. This was followed by "checks and tests for all own instruments and systems". The next step was to "release" the small aircraft, technically called the Ingenuity Helicopter Scout, from the special compartment in which it was transported and travel at a safe but acceptable distance to be able to "observe" the flight to take place. in a few days. In the online magazine two articles recently appeared referring to these operations and with a more detailed description of them, both from March a.c. and about Mars Exploration Rover and Mars Helicopters almost three years ago. The Ingenuity drone was sent to Mars to be the first man-made device to make a propelled flight to a planet other than Earth. Initially, Ingenuity rotor copter flights were scheduled for April 19 to May 19, but NASA/JPL experts felt that the date of the first takeoff could be brought forward and, at some point, estimated that place immediately after the first week of April. However, the first flight was postponed due to rotor problems, which in some situations did not enter normal operation and, for this reason, the idea arose that no scenario should be ignored and that anything is possible. Of the four scenarios considered, the optimal option was a successful flight and therefore the success of the operation and the worst, a total failure. All the "dark thoughts" disappeared and the JPL team had reason to rejoice on April 19, 2021, when the first flight was successfully performed. Even though Ingenuity rose from the ground in less than a minute, "NASA is celebrating what is the first controlled flight of an aircraft in another world," it wrote on April 20 in an article on bbc.com. The renowned organization of the media communications industry BBC (British Broadcasting Corporation), the largest in the world by a number of employees, has dedicated special shows to present this unique event. The $\mathrm{BBC}$, based in London, England, "informs, entertains and educates millions of people in the UK and around the world". According to the NASA announcement, the Ingenuity helicopter was able to take off, climbed to a height of about $3 \mathrm{~m}(10 \mathrm{ft})$, soared $30 \mathrm{sec}$ above the crater, descended one meter/second and landed safely on Martian soil. The total flight duration was $39.1 \mathrm{sec}$. On the website 
globalnews.ca he wrote that "The systems and algorithms onboard did all the work, so the flight was completely autonomous, says NASA." The solution of autonomy was adopted due to the long distance between Earth and Mars (over 290 million kilometers) and the time required for radio signals to travel. It is very clear that controlled flight from such a distance with a joystick "is simply excluded" (bbc.com).

This meant that while the drone controlled its movement, "NASA engineers sat, watched and waited with crossed arms." To express their joy with applause and cheers, the NASA team had to be very patient and stay for a few hours with great emotions, until the results were complete on Earth and until all the data was interpreted.

According to NASA (nasa.gov), confirmation of the successful flight came via the Perseverance rover on Mars, which transmitted the data to Earth. On the globalnews.ca website it is also written that the images with the "celebration" from NASA catch MiMi Aung breaking the notes with the so-called "backup speech", which contained the words prepared in case the flight was unsuccessful or if Ingenuity it was collapsing, that is, for a failure. MiMi Aung, 52, is a project manager at NASA's JPL (Jet Propulsion Laboratory) in Pasadena, California, where he arrived in 1990 and a senior engineer on the Mars Helicopter Ingenuity project. He said he had gone from "say you can" to "now you really can." He also told BBC News, "This is a major premiere for the human race." There has long been talking of a new "Wright Brothers moment," referring to the first controlled flights of a heavier-than-air aircraft by Wilbur and Orville Wright in December 1903 at Kill Devil Hills, a place chosen for the conditions. favorable wind. Kill Devil Hills is located 4 miles $(6 \mathrm{~km})$ from Kitty Hawk, North Carolina, a city that became world-famous due to the Wright brothers and the events of 1903. Speaking of the "Wright Brothers moment" on the Red Planet, MiMi Aung considers that he had finally arrived and briefly declared, "Here he is." NASA is planning for the Ingenuity drone helicopter to make "more adventurous flights" (bbc.com) in the next period, which will take place until mid-May.

Originally created by and for the military, drones have developed far beyond the battlefield and are now used everywhere, from oil fields to private farms. They are used to deliver packages, supervise land and help in case of disasters. Their field of application is becoming more and more varied and their parameters are expanding.

The key to increasing the range of drone applications is given by the increasing complexity of the electronic systems embedded in them. The miniaturized sensors used in today's drones allow them to be smaller than ever, lighter and more accessible, improving machine vision technology (activated by the new generation of powerful flight control systems) that gives them better autonomous navigation, obstacle avoidance and real-time analysis.
The development of drones has traditionally been difficult, expensive and time-consuming, but today, the availability of drone development platforms has changed all that. The new platforms from Intel, Infineon and Parallax make it easier than ever to implement drone applications.

From the very beginning, when people built the first aircraft, the idea of an unmanned aerial vehicle was extremely appealing. Airplanes allow us to travel fast, to have a bird's eye view of things and to move freely unaffected by obstacles on the ground. When it comes to flying, lighter aircraft are better compared to large and heavy ones at the same time, which must accommodate a human being. This implies greater complexity, higher costs and a shorter range, as a larger mass requires higher fuel consumption. Drones solve all these problems. Being unmanned, these aircraft can be made lighter, smaller and cheaper, especially since no life support is required. Thus, the vehicles focus only on the characteristics of being light, maneuverable and with the widest possible range. Without the risks of causing human problems, drones can also perform more dangerous tasks than those with a human pilot. Therefore, it is not surprising that drones have deep roots in the military zone.

Unmanned aerial vehicles first appeared in the 1930s. Early drone developments included balloons designed to drop bombs on enemy lines at certain intervals and unmanned aerial vehicles with explosives on board, intended to crash after a given number of rotations. of the engine. The advancement of radio technology has led to better navigation. One of the first Radio-Controlled (RC) drones was used during World War II to train anti-aircraft targets on how to fire realistically moving aerial targets. Since then, the pace of drone development has increased and they have been used more and more in today's combat scenes. Drones have been used since the 1970s in major conflicts around the world.

Ingenuity successfully made its first flight to Mars (Fig. 6).

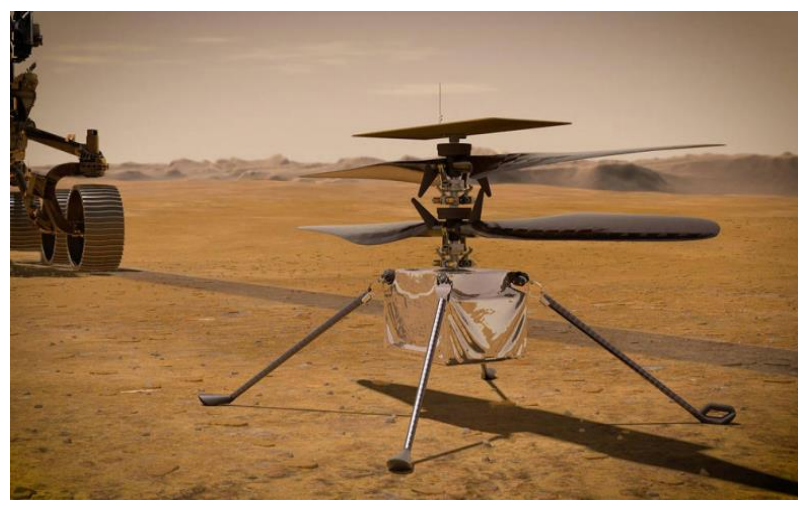

Fig. 6: Ingenuity successfully made its first flight to Mars 
While drones have been used in a military context for a considerable time, only in this decade have they become sufficiently accessible to enter the consumer market.

Drones for personal use have become possible thanks to innovative technologies in the area of Micro-ElectroMechanical Systems (MEMS), driven by the demands of the smartphone market.

Air navigation requires complex sensors to monitor physical orientation as well as acceleration on 3 different axes. In the past, this involved the use of expensive Inertial Measurement Units (IMUs) consisting of accelerometers, gyroscopes and magnetometers. These macro-sized sensory units were large, heavy and extremely expensive, limiting their use to professional aerospace, naval and defense applications.

Using the same techniques that are applied to semiconductor manufacturing technologies, MEMS technology reduces the size of accelerometers, gyroscopes and magnetometers, allowing them to be much smaller, cheaper and even safer to operate. Today, a 9-axis sensor, such as the Bosch BNO055 that measures compass orientation, physical orientation and 3-axis acceleration, can be the size of a small chip, smaller than a nail.

The extraordinary size and mass reduction of MEMSbased IMU devices have allowed them to drive drones today and their low price has meant that drones can be accessible to the average user or small businesses, once drones began to fall into the hands of everyday users and small businesses, their use improved and diversified. Today, drones are used in all applications from logistics to rescue operations.

\section{Discussion}

For logistics applications, drones have been used to deliver packages quickly and efficiently. Their ability to fly allows them to overcome traffic and navigate over obstacles on earth. Not only can drones deliver faster and more efficiently than humans, but they can also deliver to areas and places where people cannot reach easily. Do you live on the 15 th floor of a block of flats? A drone can deliver a package directly to your balcony. If you decide on an unscheduled picnic in the park, a drone can deliver pizza directly to the location indicated by your smartphone's GPS.

The ability of drones to map 3D areas quickly and accurately has transformed surveillance and offered the potential to change various industries as well as tourism. A remotely controlled drone with a high-precision GPS can get detailed photos of large areas in just a few hours or minutes. These high-resolution photos can then be put together with specific software to build an incredibly accurate 3D terrain map. Areas that once required a ground team to work for weeks can now be seen in just a few days, thanks to drones.

Drones are also useful in disaster search and rescue operations. Immediately after natural disasters, key infrastructure (such as roads and electricity) can be severely affected, making it difficult to find ground-based solutions quickly and efficiently. In these situations, drones can conduct aerial surveillance of areas to find out the location and condition of a disaster or to search for injured people. Drones can even provide first aid by providing critical products, such as food or medicine for victims in monitored areas.

As miniaturized, wirelessly controlled aircraft, drones are a technological pinnacle. They have some of the latest navigation, computing and aeronautical technologies we have today. A drone consists of a chassis, rotors, engines, speed controllers, a battery and a flight controller. While mechanical aspects such as rotors, chassis type and engine determine the flight characteristics and load-bearing capacity, the existing electronic systems onboard distinguish modern drones from yesterday's RC airplanes and helicopters.

Each rotor and the corresponding motor have an Electronic Speed Controller (ESC) that controls the speed of the motor. The ESC is a mixed-signal circuit that provides high-resolution three-phase AC power to control brushless motors based on a control signal. Connected to a motor and battery, ESCs are sized according to the amount of current they can control.

In addition to ESC, the flight controller is another essential electronic system onboard a drone. While RC airplanes and helicopters give operators direct control over engine speed, modern drones have multiple rotors and the complexity of rotor speed coordination requires an automatic system. The flight controller uses an array of sensors such as GPS, gyroscope, accelerometer, compass and barometer to stabilize and navigate the drone by adjusting the rotor speed.

Modern flight controllers range from simple stability control to completely autonomous navigation with the avoidance of obstacles using machine-vision technology - possible on advanced platforms such as Intel's Aero computer.

Although there is a certain joy in building your own drone from the sketch level, this requires a lot of time, effort and perseverance. Fortunately, Unmanned Aerial Vehicle (UAV) platforms are available today, allowing you to choose exactly how deep you want to dig. Perhaps the most complete and flexible UAV platform to date is Intel's Aero series. It can come either as a computer board with a flight controller or as a "flight-ready" drone development platform.

In the ready-to-fly option, Intel's Aero drone is a fully assembled quadrocopter running Linux on a multi-core Atom SoC processor. It has pre-installed flight controller software - allowing users to use the drone immediately after removing it from the box, without the need for further programming. The Aero flight-ready platform allows users to immediately focus on developing complex applications, instead of wasting time with flight control mechanics. 
The Aero drone also has multiple cameras, including an Intel RealSense TM R200 front camera. The R200 is a camera-based camera system with depth detection technology, including conventional dual cameras as well as an infrared camera and an infrared laser projector. Stereo vision and infrared components allow obtaining 3D images with the ability to detect depth. It can be used for collision avoidance, surveillance, 3D mapping and more. In addition to being sold as a complete, flight-ready drone, the Aero platform is also available as an optional dashboard with a Real Sense camera and camera, which allows the integration of computing capabilities and machine vision technology on other multi-copter drone chassis.

Although they were once just simple toys for enthusiasts, today's drones have penetrated many markets and are targeting many more. At the same time, developing drone applications has never been easier. For those who want to directly access an advanced drone application development environment, Intel's Aero platform offers a ready-to-fly solution and for those who want to work on development themselves, integrated components from vendors such as Infineon and Cypress can significantly reduce development times and costs (Patrick, 2018).

\section{Conclusion}

Given the declining planetary resources and increasing their consumption, at least some of them could be brought from outside the planet, such as metals or diamonds, so as not we try to find them or supplements in the depths of the earth, so as not to disturb the balance of our planet.

The use of drones instead of massive, classic aircraft could bring a massive saving of materials, but also a decrease in total costs used a drastic reduction in the nuisances caused by more and more flights, a relaxation of air traffic, with better control and may with much higher flight safety. The performance of drones cannot be matched by the classic aircraft used so far, which is why drones will gradually take the place of classic aircraft, massive and expensive, but also with a fairly high frequency of accidents and with major risks on passengers and goods transported.

Obviously, in the future, the drones will carry out the transport of goods and even passengers on short and medium distances, but even on longer routes, bringing the aerial technique to its peak and even more than that, all the drones will be called to replace the robotic and aerial modules on the planets that will be further explored, including the red planet, our nearest neighbor.

\section{Acknowledgement}

The work was appreciated by teams of professors from the departments of automobiles from several universities in Romania and Italy. This text was acknowledged and appreciated by Associate Professor Aniello Riccio seconda Universita' Degli Studi di Napoli Italy, whom we thanks and in this way.

\section{Funding Information}

Research contract: Contract number 36-5-4D/1986 from 24IV1985, beneficiary CNST RO (Romanian National Center for Science and Technology) Improving dynamic mechanisms internal combustion engines. All these matters are copyrighted. Copyrights: 548-cgiyw Dssin, from: 22-04-2010, 08:48:48.

\section{Ethics}

Author declares that are not ethical issues that may arise after the publication of this manuscript. This article is original and contains unpublished material.

\section{References}

Abam, F. I., Ugot, I. U., \& Igbong, D. I. (2012). Performance analysis and components irreversiblities of a (25 MW) gas turbine power plant modeled with a spray cooler. American Journal of Engineering and Applied Sciences, 5(1), 35-41. https://doi.org/10.3844/ajeassp.2012.35.41

Abdelkrim, H., Othman, S. B., Salem, A. K. B., \& Saoud, S. B. (2012). Dynamic partial reconfiguration contribution on system on programmable chip architecture for motor drive implementation. American Journal Engineering Applied Sciences, 5, 15-24. https://doi.org/10.3844/ajeassp.2012.15.24

Abdullah, H., \& Halim, S. A. (2009). Electrical and Magnetoresistive studies Nd doped on La-Ba-Mn-O sub (3) Manganites for Lowfield Sensor application. American Journal of Engineering and Applied Sciences, 2(2). https://doi.org/10.3844/ajeassp.2009.297.303

Abdullah, M. Z., Saat, A., \& Hamzah, Z. (2011). Optimization of energy dispersive $\mathrm{X}$-ray fluorescence spectrometer to analyze heavy metals in moss samples. American Journal of Engineering and Applied Sciences, 4(3). https://doi.org/10.3844/ajeassp.2011.355.362

Abdullah, M., A. F.M. Zain, Y. H. Ho and S. Abdullah, 2009. TEC and scintillation study of equatorial ionosphere: A month campaign over sipitang and parit raja stations, Malaysia. American Journal Engineering Applied Sciences, 2: 44-49. https://doi.org/10.3844/ajeassp.2009.44.49

Abouobaida, H. (2016). Robust and efficient controller to design a standalone source supplied DC and AC load powered by photovoltaic generator. American Journal Engineering Applied Sciences, 9, 894-901. https://doi.org/10.3844/ajeassp.2016.894.901 
Ab-Rahman, M. S., Guna, H., Harun, M. H., Zan, S. D., \& Jumari, K. (2009). Cost-effective fabrication of self-made $1 \times 12$ polymer optical fiber-based optical splitters for automotive application. American Journal Engineering Applied Sciences, 2, 252-259. https://doi.org/10.3844/ajeassp.2009.252.259

Abu-Ein, S. (2009). Numerical and analytical study of exhaust gases flow in porous media with applications to diesel particulate filters. American Journal Engineering Applied Sciences, 2, 70-75. https://doi.org/10.3844/ajeassp.2009.70.75

Abu-Lebdeh, T. M., Leon, G. P. D., Hamoush, S. A., Seals, R. D., \& Lamberti, V. E. (2016). Gas atomization of molten metal: Part II. Applications. American Journal of Engineering and Applied Sciences, 9(2). https://doi.org/10.3844/ajeassp.2016.334.349

Agarwala, S. (2016). A perspective on 3D bioprinting technology: Present and future. American Journal Engineering Applied Sciences, 9, 985-990.

Ahmed, M., Khan, R., Billah, M., \& Farhana, S. (2010). A novel navigation algorithm for hexagonal hexapod robot. American Journal Engineering Applied Sciences, 3, 320-327. https://doi.org/10.3844/ajeassp.2010.320.327

Ahmed, R., Khan, M., Haque, H., \& Rahman, H. (2016). An approach to develop a dynamic job shop scheduling by fuzzy rule-based system and comparative study with the traditional priority rules. American Journal Engineering Applied Sciences, 9, 202-212. https://doi.org/10.3844/ajeassp.2016.202.212

Akhesmeh, S., Pourmahmoud, N., \& Sedgi, H. (2008). Numerical study of the temperature separation in the Ranque-Hilsch vortex tube. American Journal of Engineering and Applied Sciences, 1(3). https://doi.org/10.3844/ajeassp.2008.181.187

Al Qadi, A. N. S., ALhasanat, M. B., Dahamsheh, A. A., \& Zaiydneen, S. A. (2016a). Using of box-benken method to predict the compressive strength of selfcompacting concrete containing Wadi Musa bentonite, Jordan. American Journal Engineering Applied Sciences, 9, 406-411. https://doi.org/10.3844/ajeassp.2016.406.411

Al Qadi, A. N., Alhasanat, M. B., \& Haddad, M. (2016b). Effect of crumb rubber as coarse and fine aggregates on the properties of asphalt concrete. American Journal Engineering Applied Sciences, 9, 558-564. https://doi.org/10.3844/ajeassp.2016.558.564

Al Smadi, T. A. (2011). Low cost smart sensor design. American Journal Engineering Applied Sciences, 4, 162-168. https://doi.org/10.3844/ajeassp.2011.162.168

Al-Abbas, I. K. (2009). Reduced order models of a current source inverter induction motor drive. American Journal Engineering Applied Sciences, 2, 39-43. https://doi.org/10.3844/ajeassp.2009.39.43
Aleksic, S., \& Lovric, A. (2011). Energy consumption and environmental implications of wired access networks. American Journal Engineering Applied Sciences, 4, 531-539. https://doi.org/10.3844/ajeassp.2011.531.539

Al-Hasan, M. I., \& Al-Ghamdi, A. S. (2016). Energy balance for a diesel engine operates on a pure biodiesel, diesel fuel and biodiesel-diesel blends. American Journal Engineering Applied Sciences, 9, 458-465. https://doi.org/10.3844/ajeassp.2016.458.465

Alhasanat, M. B., Al Qadi, A. N., Al Khashman, O. A., \& Dahamsheh, A. (2016). Scanning electron microscopic evaluation of self-compacting concrete spalling at elevated temperatures. American Journal Engineering Applied Sciences, 9, 119-127. https://doi.org/10.3844/ajeassp.2016.119.127

Ali, G. A. M., Fouad, O., \& Makhlouf, S. A. (2016). Electrical properties of cobalt oxide/silica nanocomposites obtained by sol-gel technique. American Journal Engineering Applied Sciences, 9, 12-16. https://doi.org/10.3844/ajeassp.2016.12.16

Ali, K. S., \& Shumaker, J. L. (2013). Hardware in the loop simulator for multi agent unmanned aerial vehicles environment. American Journal of Engineering and $\begin{array}{lll}\text { Applied } \quad \text { Sciences, } & 6(2),\end{array}$ https://doi.org/10.3844/ajeassp.2013.172.177

Alwetaishi, M. S. (2016). Impact of building function on thermal comfort: A review paper. American Journal Engineering Applied Sciences, 9, 928-945. https://doi.org/10.3844/ajeassp.2016.928.945

Aly, W. M., \& Abuelnasr, M. S. (2010). Electronic design automation using object oriented electronics. American Journal of Engineering and Applied Sciences, 3(1). https://doi.org/10.3844/ajeassp.2010.121.127

Amani, N. (2016). Design and implementation of optimum management system using cost evaluation and financial analysis for prevention of building failure. American Journal Engineering Applied Sciences, 9, 281-296. https://doi.org/10.3844/ajeassp.2016.281.296

Anizan, S., Yusri, K., Leong, C. S., Amin, N., Zaidi, S., \& Sopian, K. (2011). Effects of the contact resistivity variations of the screen-printed silicon solar cell. American Journal Engineering Applied Sciences, 4, 328-331. https://doi.org/10.3844/ajeassp.2011.328.331

Ascione, F., Bianco, N., De Masi, R. F., De Rossi, F., De Stasio, C., \& Vanoli, G. P. (2016). Energy audit of health care facilities: Dynamic simulation of energy performances and energy-oriented refurbishment of system and equipment for microclimatic control. https://doi.org/10.3844/ajeassp.2016.814.834

Augustine, A., Prakash, R. D., Xavier, R., \& Parassery, M. C. (2016). Review of signal processing techniques for detection of power quality events. American Journal Engineering Applied Sciences, 9, 364-370. https://doi.org/10.3844/ajeassp.2016.364.370 
Aversa, R., Petrescu, F. I., Petrescu, R. V., \& Apicella, A. (2016a). Biomimetic finite element analysis bone modeling for customized hybrid biological prostheses development. American Journal of Applied Sciences, 13(11), 1060-1067. https://doi.org/10.3844/ajassp.2016.1060.1067

Aversa, R., Parcesepe, D., Petrescu, R. V. V., Chen, G., Petrescu, F. I. T., Tamburrino, F., \& Apicella, A. (2016b). Glassy amorphous metal injection molded induced morphological defects. https://doi.org/10.3844/ajassp.2016.1476.1482

Aversa, R., Petrescu, R. V., Petrescu, F. I., \& Apicella, A. (2016c). Smart-factory: Optimization and process control of composite centrifuged pipes. American Journal of Applied Sciences, 13(11), 1330-1341. https://doi.org/10.3844/ajassp.2016.1330.1341

Aversa, R., Tamburrino, F., Petrescu, R. V., Petrescu, F. I., Artur, M., Chen, G., \& Apicella, A. (2016d). Biomechanically inspired shape memory effect machines driven by muscle like acting NiTi alloys. American Journal of Applied Sciences, 13(11), 1264-1271. https://doi.org/10.3844/ajassp.2016.1264.1271

Aversa, R., Buzea, E. M., Petrescu, R. V., Apicella, A., Neacsa, M., \& Petrescu, F. I. (2016e). Present a mechatronic system having able to determine the concentration of carotenoids. American Journal of Engineering and Applied Sciences, 9(4), 1106-1111. https://doi.org/10.3844/ajeassp.2016.1106.1111

Aversa, R., Petrescu, R. V., Sorrentino, R., Petrescu, F. I., \& Apicella, A. (2016f). Hybrid ceramopolymeric nanocomposite for biomimetic scaffolds design and preparation. American Journal of Engineering and Applied Sciences, 9(4). https://doi.org/10.3844/ajeassp.2016.1096.1105

Aversa, R., Perrotta, V., Petrescu, R. V., Carlo, M., Petrescu, F. I., \& Apicella, A. (2016g). From structural colors to super-hydrophobicity and achromatic transparent protective coatings: Ion plating plasma assisted TiO 2 and SiO 2 nano-film deposition. https://doi.org/10.2139/ssrn.3074477

Aversa, R., Petrescu, R. V., Petrescu, F. I., \& Apicella, A. (2016h). Biomimetic and evolutionary design driven innovation in sustainable products development. American Journal of Engineering and Applied Sciences, 9(4). https://doi.org/10.3844/ajeassp.2016.1027.1036

Aversa, R., Petrescu, R. V., Apicella, A., \& Petrescu, F. I. (2016i). Mitochondria are naturally micro robots-a review. American Journal of Engineering and Applied Sciences, 9(4). https://doi.org/10.3844/ajeassp.2016.991.1002

Aversa, R., Petrescu, R. V., Apicella, A., \& Petrescu, F. I. (2016j). Mitochondria are naturally micro robots-a review. American Journal of Engineering and Applied Sciences, 9(4).

https://doi.org/10.3844/ajeassp.2016.991.1002
Aversa, R., Petrescu, R. V., Apicella, A., \& Petrescu, F. I. (2016k). Physiologic human fluids and swelling behavior of hydrophilic biocompatible hybrid ceramo-polymeric materials. American Journal of Engineering and Applied Sciences, 9(4), 962-972. https://doi.org/10.3844/ajeassp.2016.962.972

Aversa, R., Petrescu, R. V., Apicella, A., \& Petrescu, F. I. (20161). One can slow down the aging through antioxidants. American Journal of Engineering and Applied Sciences, 9(4). https://doi.org/10.3844/ajeassp.2016.1112.1126

Aversa, R., Petrescu, R. V., Apicella, A., \& Petrescu, F. I. (2016m). About homeopathy or $\ll$ Similia similibus curentur $\gg$. American Journal of Engineering and Applied Sciences, 9(4). https://doi.org/10.3844/ajeassp.2016.1164.1172

Aversa, R., Petrescu, R. V., Apicella, A., \& Petrescu, F. I. (2016n). The basic elements of life's. American Journal of Engineering and Applied Sciences, 9(4), 1189-1197. https://doi.org/10.3844/ajeassp.2016.1189.1197

Aversa, R., Petrescu, F. I., Petrescu, R. V., \& Apicella, A. (2016o). Flexible stem trabecular prostheses. American Journal of Engineering and Applied Sciences, 9(4). https://doi.org/10.3844/ajeassp.2016.1213.1221

Aversa, R., Petrescu, R. V., Apicella, A., \& Petrescu, F. I. (2017a). Nano-diamond hybrid materials for structural biomedical application. American Journal of Biochemistry and Biotechnology, 13(1), 34-41. https://doi.org/10.3844/ajbbsp.2017.34.41

Aversa, R., Parcesepe, D., Petrescu, R. V., Berto, F., Chen, G., Petrescu, F. I., ... \& Apicella, A. (2017b). Processability of bulk metallic glasses. American Journal of Applied Sciences, 14(2), 294-301. https://doi.org/10.3844/ajassp.2017.294.301

Babayemi, A. K. (2016). Thermodynamics, non-linear isotherms, statistical modeling and optimization of phosphorus adsorption from wastewater. American Journal Engineering Applied Sciences, 9, 1019-1026. https://doi.org/10.3844/ajeassp.2016.1019.1026

Bakar, R. A., Mohammed, M. K., \& Rahman, M. M. (2009). Numerical study on the performance characteristics of hydrogen fueled port injection internal combustion engine. American Journal Engineering Applied Sciences, 2, 407-415. https://doi.org/10.3844/ajeassp.2009.407.415

Barone, G., Buonomano, A., Forzano, C., \& Palombo, A. (2016). WLHP systems in commercial buildings: A case study analysis based on a dynamic simulation approach. American Journal Engineering Applied Sciences, 9, 659-668. https://doi.org/10.3844/ajeassp.2016.659.668

Bedon, C. (2016). Review on the use of FRP composites for facades and building skins. https://doi.org/10.3844/ajeassp.2016.713.723 
Bedon, C., \& Amadio, C. (2016). A unified approach for the shear buckling design of structural glass walls with non-ideal restraints. American Journal Engineering Applied Sciences, 9, 64-78. https://doi.org/10.3844/ajeassp.2016.64.78

Bedon, C., \& Louter, C. (2016). Finite-element numerical simulation of the bending performance of post-tensioned structural glass beams with adhesively bonded cfrp tendons. https://doi.org/10.3844/ajeassp.2016.680.691

Bolonkin, A. (2009a). Femtotechnology: Nuclear matter with fantastic properties. American Journal Engineering Applied Sciences, 2(2), 501-514. https://doi.org/10.3844/ajeassp.2009.501.514

Bolonkin, A. A. (2009b). Converting of matter to nuclear energy by ab-generator. American Journal Engineering Applied Sciences, 2, 683-693. https://doi.org/10.3844/ajeassp.2009.683.693

Boucetta, A. (2008). Vector control of a variable reluctance machine stator and rotor discs imbricates. American Journal of Engineering and Applied Sciences, 1(4). https://doi.org/10.3844/ajeassp.2008.260.265

Bucinell, R. B. (2016). Stochastic model for variable amplitude fatigue induced delamination growth in graphite/epoxy laminates. American Journal Engineering Applied Sciences, 9, 635-646. https://doi.org/10.3844/ajeassp.2016.635.646

Budak, S., Xiao, Z., Johnson, B., Cole, J., Drabo, M., Tramble, A., \& Casselberry, C. (2016). High Efficient Advanced Thermoelectric Devices from Different Multilayer Thin Films. https://doi.org/10.3844/ajeassp.2016.356.363

Buonomano, A., Calise, F., \& Vicidomini, M. (2016a). A novel prototype of a small-scale solar power plant: Dynamic simulation and thermoeconomic analysis. American Journal Engineering Applied Sciences, 9, 770-788. https://doi.org/10.3844/ajeassp.2016.770.788

Buonomano, A., Calise, F., d'Accadia, M. D., Vanoli, R., \& Vicidomini, M. (2016b). Simulation and experimental analysis of a demonstrative solar heating and cooling plant installed in Naples (Italy). American Journal Engineering Applied Sciences, 9, 798-813. https://doi.org/10.3844/ajeassp.2016.798.813

Calise, F., Dâ'Accadia, M. D., Libertini, L., Quiriti, E., \& Vicidomini, M. (2016). Dynamic simulation and optimum operation strategy of a trigeneration system serving a hospital. American Journal Engineering Applied Sciences, 9, 854-867. https://doi.org/10.3844/ajeassp.2016.854.867

Campo, T., Cotto, M., Márquez, F., Elizalde, E., \& Morant, C. (2016). Graphene Synthesis by PlasmaEnhanced CVD Growth with Ethanol. American Journal of Engineering and Applied Sciences, 9(3). https://doi.org/10.3844/ajeassp.2016.574.583
Cardu, M., Oreste, P., \& Cicala, T. (2009). Analysis of the tunnel boring machine advancement on the Bologna-Florence railway link. American Journal Engineering Applied Sciences, 2, 416-420. https://doi.org/10.3844/ajeassp.2009.416.420

Catana, R. M., Cican, G., \& Dediu, G. (2017). Gas Turbine Engine Starting Applicated on TV2-117 Turboshaft. Engineering, Technology \& Applied Science Research, 7(5), 2005-2009.

http://etasr.com/index.php/ETASR/article/view/1315

Chen, G., \& Xu, L. (2016). A general strategy to enhance up conversion luminescence in rare-earthion-doped oxide nanocrystals. American Journal Engineering Applied Sciences, 9, 79-83. https://doi.org/10.3844/ajeassp.2016.79.83

Chiozzi, A., Milani, G., Grillanda, N., \& Tralli, A. (2016). An adaptive procedure for the limit analysis of FRP reinforced masonry vaults and applications. https://doi.org/10.3844/ajeassp.2016.735.745

Chisari, C., \& Bedon, C. (2016). Multi-objective optimization of FRP jackets for improving the seismic response of reinforced concrete frames. https://doi.org/10.3844/ajeassp.2016.669.679

Cican, G., Deaconu, M., Mirea, R., Ceatra, L., Cretu, M., \& Dobre, T. (2020). Investigating the Use of Recycled Pork Fat-Based Biodiesel in Aviation Turbo Engines. Processes, 8(9), 1196. https://doi.org/10.3390/pr8091196

Cican, G., Plesu, V., Deaconu, M., Toma, A., \& Cretu, M. (2019). Performances and emissions evaluation of a microturbojet engine running on biodiesel blends. Journal of Energy Resources Technology, 141(7). https://doi.org/10.1115/1.4042718

Cican, G., Toma, A., Puşcaşu, C., \& Catana, R. (2018). Jet CAT P80 Thermal Analyses and Performance Assessment Using Different Fuels Types. Journal of Thermal Science, 27(4), 389-393. https://doi.org/10.1007/s11630-018-1026-z

Darabi, A., Soleamani, S. A., \& Hassannia, A. (2008). Fuzzy based digital automatic voltage regulator of a synchronous generator with unbalanced loads. American Journal of Engineering and Applied Sciences, 1(4), 280-286. https://doi.org/10.3844/ajeassp.2008.280.286

Darwazeh, I., \& Ahmed, S., (2011). Inverse discrete Fourier transform-discrete Fourier transform techniques for generating and receiving spectrally efficient frequency division multiplexing signals. American Journal of Engineering and Applied Sciences, 4, 598-606. https://doi.org/10.3844/ajeassp.2011.598.606

Daud, H., Yahya, N., Aziz, A. A., \& Jusoh, M. F. (2008). Development of wireless electric concept powering electrical appliances. American Journal Engineering Applied Sciences, 1, 12-15. https://doi.org/10.3844/ajeassp.2008.12.15 
Deaconu, M., Cican, G., \& Cristea, L. (2020). Noise Impact Mitigation of Shopping Centres Located near Densely Populated Areas for a Better Quality of Life. Applied Sciences, 10(18), 6484. https://doi.org/10.3390/app10186484

Deaconu, M., \& Cican, G. (2018). Turbojet Test Cell and Noise Impact Assessment in the Vicinity of Romanian Research and Development Institute for Gas Turbines COMOTI. Acoustics Australia, 46(2), 249-257. https://doi.org/10.1007/s40857018-0134-y

Djalel, D., Mourad, M., \& Labar, H. (2013). New approach of electromagnetic fields of the lightning discharge. American Journal Engineering Applied Sciences, 6, 369-383. https://doi.org/10.3844/ajeassp.2013.369.383

Dos Santos, F. A., \& Bedon, C. (2016). Preliminary experimental and finite-element numerical assessment of the structural performance of SMAreinforced GFRP systems. American Journal of Engineering and Applied Sciences, 9(3), 692-701. https://doi.org/10.3844/ajeassp.2016.692.701

Ebrahim, A.N., Ahmed, S., Abdul Rashid, S. H., \& Taha, Z. (2012). Technology use in the virtual R\&D teams. American Journal of Engineering and Applied Sciences, 5(1), 9-14. https://doi.org/10.3844/ajeassp.2012.9.14

El-Labban, H. F., Abdelaziz, M., \& Mahmoud, E. R. (2013). Modification of carbon steel by laser surface melting: Part I: Effect of laser beam travelling speed on microstructural features and surface hardness. American Journal Engineering Applied Sciences, 6, 352-359. https://doi.org/10.3844/ajeassp.2013.384.392

Elliott, A., AlSalihi, S., Merriman, A. L., \& Basti, M. M. (2016). Infiltration of nanoparticles into porous binder jet printed parts. American Journal of Engineering and Applied Sciences, 9(1). https://doi.org/10.3844/ajeassp.2016.128.133

El-Tous, Y. (2008). Pitch angle control of variable speed wind turbine. American Journal of Engineering and Applied Sciences, 1(2), 118-120. https://doi.org/10.3844/ajeassp.2008.118.120

Faizal, A., Mulyono, S., Yendra, R., \& Fudholi, A. (2016). Design Maximum Power Point Tracking (MPPT) on photovoltaic panels using fuzzy logic method. American Journal Engineering Applied Sciences, 9, 789-797. https://doi.org/10.3844/ajeassp.2016.789.797

Farahani, A. S., Adam, N. M., \& Ariffin, M. K. A. (2010). Simulation of airflow and aerodynamic forces acting on a rotating turbine ventilator. American Journal Engineering Applied Sciences, 3, 159-170. https://doi.org/10.3844/ajeassp.2010.159.170

Fathallah, A. Z. M., \& Bakar, R. A. (2009). Prediction studies for the performance of a single cylinder high speed spark ignition linier engine with spring mechanism as return cycle. American Journal of Engineering and Applied Sciences, 2(4). https://doi.org/10.3844/ajeassp.2009.713.720
Fen, Y. W., Yunus, W. M. M., \& Yusof, N. A. (2011). Optical properties of cross-linked chitosan thin film for copper ion detection using surface plasmon resonance technique. Opt. Application, 41(4), 999-1013. https://doi.org/10.3844/ajeassp.2011.61.65

Feraga, C. E., Moussaoui, A., Bouldjedri, A., \& Yousfi, A. (2009). Robust position controller for a permanent magnet synchronous actuator. American Journal of Engineering and Applied Sciences, 2(2). https://doi.org/10.3844/ajeassp.2009.388.392

Gusti, A. P., \& Semin, (2016). The effect of vessel speed on fuel consumption and exhaust gas emissions. American Journal Engineering Applied Sciences, 9, 1046-1053. https://doi.org/10.3844/ajeassp.2016.1046.1053

Hasan, S., \& El-Naas, M. H. (2016). Optimization of a combined approach for the treatment of carbide slurry and capture of CO2. American Journal Engineering Applied Sciences, 9, 449-457. https://doi.org/10.3844/ajeassp.2016.449.457

Hassan, M., Mahjoub, H., \& Obed, M. (2012). Voicebased control of a DC servo motor. American Journal of Engineering and Applied Sciences, 5(1). https://doi.org/10.3844/ajeassp.2012.89.92

Helmy, A. K., \& El-Taweel, G. S. (2010). Neural network change detection model for satellite images using textural and spectral characteristics. American Journal of Engineering and Applied Sciences, 3(4). https://doi.org/10.3844/ajeassp.2010.604.610

Hirun, W. (2016). Evaluation of interregional freight generation modelling methods by using nationwide commodity flow survey data. American Journal Engineering Applied Sciences, 9, 625-634. https://doi.org/10.3844/ajeassp.2016.625.634

Ho, C. Y. F., Ling, B. W. K., Giovanni, B. S., Chi, Z. W., \& Siu, W. C. (2011). Single step optimal block matched motion estimation with motion vectors having arbitrary pixel precisions. In 2010 7th International Symposium on Communication Systems, Networks \& Digital Signal Processing (CSNDSP 2010) (pp. 316-326). IEEE. https://doi.org/10.3844/ajeassp.2016.985.990

Huang, B., Masood, S. H., Nikzad, M., Venugopal, P. R., \& Arivazhagan, A. (2016). Dynamic mechanical properties of fused deposition modelling processed polyphenylsulfone material. American Journal Engineering Applied Sciences, 9, 1-11. https://doi.org/10.3844/ajeassp.2016.1.11

Iqbal, M. (2016). An overview of Energy Loss Reduction (ELR) software used in Pakistan by WAPDA for calculating transformer overloading, line losses and energy losses. American Journal Engineering Applied Sciences, 9, 442-448. https://doi.org/10.3844/ajeassp.2016.442.448 
Ismail, M. I. S., Okamoto, Y., Okada, A., \& Uno, Y. (2011). Experimental investigation on micro-welding of thin stainless steel sheet by fiber laser. American Journal Engineering Applied Sciences, 4, 314-320. https://doi.org/10.3844/ajeassp.2011.314.320

Jaber, A. A., \& Bicker, R. (2016). Industrial robot fault detection based on statistical control chart. American Journal Engineering Applied Sciences, 9, 251-263. https://doi.org/10.3844/ajeassp.2016.251.263

Jafari, N., Alsadoon, A., Withana, C. P., Beg, A., \& Elchouemi, A. (2016). Designing a comprehensive security framework for smartphones and mobile devices. American Journal of Engineering and Applied Sciences, 9(3), 724-734. https://doi.org/10.3844/ajeassp.2016.724.734

Jalil, M. I. A. \& Sampe, J. (2013). Experimental investigation of thermoelectric generator modules with different technique of cooling system. American Journal of Engineering and Applied Sciences, 6(1), 1-7. https://doi.org/10.3844/ajeassp.2013.1.7

Jaoude, A. A. \& El-Tawil, K. (2013). Analytic and nonlinear prognostic for vehicle suspension systems. American Journal of Engineering and Applied Sciences, 6(1), 42-56. https://doi.org/10.3844/ajeassp.2013.42.56

Jarahi, H. (2016). Probabilistic seismic hazard deaggregation for Karaj City (Iran). American Journal Engineering Applied Sciences, 9, 520-529. https://doi.org/10.3844/ajeassp.2016.520.529

Jarahi, H., \& Seifilaleh, S. (2016). Rock fall hazard zonation in Haraz Highway. American Journal Engineering Applied Sciences, 9, 371-379. https://doi.org/10.3844/ajeassp.2016.371.379

Jauhari, K., Widodo, A., \& Haryanto, I. (2016). Identification of a machine tool spindle critical frequency through modal and imbalance response analysis. American Journal Engineering Applied Sciences, 9, 213-221. https://doi.org/10.3844/ajeassp.2016.213.221

Jiang, J., Chen, Q., \& Nimbalkar, S. (2016). Field data based method for predicting long-term settlements. https://doi.org/10.3844/ajeassp.2016.466.476

Kaewnai, S., \& Wongwises, S. (2011). Improvement of the runner design of francis turbine using computational fluid dynamics. American Journal Engineering Applied Sciences, 4, 540-547. https://doi.org/10.3844/ajeassp.2011.540.547

Kamble, V. G., \& Kumar, N. (2016). Fabrication and tensile property analysis of polymer matrix composites of graphite and silicon carbide as fillers. American Journal Engineering Applied Sciences, 9, 17-30. https://doi.org/10.3844/ajeassp.2016.17.30

Kazakov, V. V., Pavlikov, A. I., Kamensky, V. A., Yusupov, V. I., \& Bagratashvili, V. N. (2016). Control of bubble formation at the optical fiber tip by analyzing ultrasound acoustic waves. American Journal of Engineering and Applied Sciences, 9(4), 921-927. https://doi.org/10.3844/ajeassp.2016.921.927
Kechiche, O. B. H. B., Sethom, H. B. A., Sammoud, H., \& Belkhodja, I. S. (2011). Optimized high frequency signal injection based permanent magnet synchronous motor rotor position estimation applied to washing machines. American Journal of Engineering and Applied Sciences, 4(3). https://doi.org/10.3844/ajeassp.2011.390.399

Kuli, I., Abu-Lebdeh, T. M., Fini, E. H., \& Hamoush, S. A. (2016). The use of nano-silica for improving mechanical properties of hardened cement paste. American Journal Engineering Applied Sciences, 9, 146-154. https://doi.org/10.3844/ajeassp.2016.146.154

Kunanoppadon, J. (2010). Thermal efficiency of a combined turbocharger set with gasoline engine. American Journal Engineering Applied Sciences, 3, 342-349. https://doi.org/10.3844/ajeassp.2010.342.349

Kwon, S., Tani, Y., Okubo, H., \& Shimomura, T. (2010). Fixed-star tracking attitude control of spacecraft using single-gimbal control moment gyros. American Journal Engineering Applied Sciences, 3, 49-55. https://doi.org/10.3844/ajeassp.2010.49.55

Lamarre, A., Fini, E. H., \& Abu-Lebdeh, T. M. (2016). Investigating effects of water conditioning on the adhesion properties of crack sealant. American Journal Engineering Applied Sciences, 9, 178-186. https://doi.org/10.3844/ajeassp.2016.178.186

Elmeddahi, Y., Mahmoudi, H., Issaadi, A., Goosen, M. F., \& Ragab, R. (2016). Evaluating the effects of climate change and variability on water resources: A case study of the Cheliff Basin in Algeria. American Journal of Engineering and Applied Sciences, 9(4), 835-845. https://doi.org/10.3844/ajeassp.2016.835.845

Lubis, Z., Abdalla, A. N., Mortaza, M., \& Ghon, R. (2009). Mathematical Modeling of the Three Phase Induction Motor Couple to DC Motor in Hybrid Electric Vehicle. American Journal of Engineering and Applied Sciences, 2(4). https://doi.org/10.3844/ajeassp.2009.708.712

Madani, D.A.L. \& Dababneh, A. (2016). Rapid entire body assessment: A literature review. American Journal of Engineering and Applied Sciences, 9(1), 107-118. https://doi.org/10.3844/ajeassp.2016.107.118

Malomar, G. E., Gueye, A., Mbow, C., Traore, V. B., \& Beye, A. C. (2016). Numerical study of natural convection in a square porous cavity thermally modulated on both side walls. American Journal Engineering Applied Sciences, 9, 591-598. https://doi.org/10.3844/ajeassp.2016.591.598

Mansour, M. A. (2016). Developing an anthropometric database for Saudi students and comparing Saudi dimensions relative to Turkish and Iranian peoples. American Journal of Engineering and Applied Sciences, 9(3), 547-557. https://doi.org/10.3844/ajeassp.2016.547.557 
Marghany, M., \& Hashim, M. (2009). Robust of doppler centroid for mapping sea surface current by using radar satellite data. American Journal Engineering Applied Sciences, 2, 781-788. https://doi.org/10.3844/ajeassp.2009.781.788

Patrick, M. (2018). Drone - an ongoing journey. https:/www.electronica-azi.ro/2018/10/01/drone-ocalatorie-in-desfasurare/

Martins, F. R., Gonçalves, A. R., \& Pereira, E. B. (2016). Observational study of wind shear in northeastern Brazil. American Journal Engineering Applied Sciences, 9, 484-504. https://doi.org/10.3844/ajeassp.2016.484.504

Mavukkandy, M. O., Chakraborty, S., Abbasi, T., \& Abbasi, S. A. (2016). A clean-green synthesis of platinum nanoparticles utilizing a pernicious weed lantana (Lantana Camara). American Journal Engineering Applied Sciences, 9, 84-90. https://doi.org/10.3844/ajeassp.2016.84.90

Minghini, F., Tullini, N., \& Ascione, F. (2016). Updating Italian design guide CNR DT-205/2007 in view of recent research findings: Requirements for pultruded FRP profiles. https://doi.org/10.3844/ajeassp.2016.702.712

Moezi, N., Dideban, D., \& Ketabi, A. (2008). A novel integrated SET based inverter for nano power electronic applications. American Journal Engineering Applied Sciences, 1, 219-222. https://doi.org/10.3844/ajeassp.2008.219.222

Mohamed, M. A., Tuama, A. Y., Makhtar, M., Awang, M. K., \& Mamat, M. (2016). The effect of RSA exponential key growth on the multi-core computational resource. American Journal Engineering Applied Sciences, 9, 1054-1061. https://doi.org/10.3844/ajeassp.2016.1054.1061

Mohan, S. R. K., Jayabalan, P., \& Rajaraman, A. (2012). Properties of fly ash based coconut fiber composite. American Journal of Engineering and Applied Sciences, 5(1). https://doi.org/10.3844/ajeassp.2012.29.34

Mohseni, E., \& Tsavdaridis, K. D. (2016). Effect of nanoalumina on pore structure and durability of Class $\mathrm{F}$ Fly ash self-compacting mortar. American Journal of Engineering and Applied Sciences, 9(2), 323-333. https://doi.org/10.3844/ajeassp.2016.323.333

Momani, M. A., Al Smadi, T. A., Al Taweel, F. M., \& Ghaidan, K. A. (2011). GPS ionospheric total electron content and scintillation measurements during the October 2003 magnetic storm. American Journal Engineering Applied Sciences, 4, 301-306. https://doi.org/10.3844/ajeassp.2011.301.306

Mondal, R., Sahoo, S., \& Rout, C. S. (2016). Mixed nickel cobalt manganese oxide nanorods for supercapacitor application.

https://doi.org/10.3844/ajeassp.2016.540.546
Montgomery, J., Abu-Lebdeh, T. M., Hamoush, S. A., \& Picornell, M. (2016). Effect of nano-silica on the compressive strength of harden cement paste at different stages of hydration. American Journal Engineering Applied Sciences, 9, 166-177. https://doi.org/10.3844/ajeassp.2016.166.177

Morse, A., Mansfield, M. M., Alley, R. M., Kerr, H. A., \& Bucinell, R. B. (2016). Traction enhancing products affect maximum torque at the shoe-floor interface: A potential increased risk of ACL injury. American Journal Engineering Applied Sciences, 9, 889-893. https://doi.org/10.3844/ajeassp.2016.889.893

Moubarek, T., \& Gharsallah, A. (2016). A six-port reflectometer calibration using Wilkinson power divider. American Journal Engineering Applied Sciences, 9, 274-280. https://doi.org/10.3844/ajeassp.2016.274.280

Nabilou, A. (2016). Effect of parameters of selection and replacement drilling bits based on geomechanical factors:(Case study: Gas and oil reservoir in the Southwest of Iran). American Journal Engineering Applied Sciences, 9, 380-395. https://doi.org/10.3844/ajeassp.2016.380.395

Nabilou, A., Carvalho, M. T., Dias, N., Brogueira, P., Salamunićcar, G., Loncaric, S., ... \& Gonçalves, M. C. (2016). Study of the parameters of Steam Assisted Gravity Drainage (SAGD) method for enhanced oil recovery in a heavy oil fractured carbonate reservoir. American Journal Engineering Applied Sciences, 9, 647-658. https://doi.org/10.3844/ajeassp.2016.647.658

Nachiengtai, T., Chim-Oye, W., Teachavorasinskun, S., \& Sa-Ngiamvibool, W. (2008). Identification of shear band using elastic shear wave propagation. American Journal of Engineering and Applied Sciences, 1(3). https://doi.org/10.3844/ajeassp.2008.188.191

Nahas, R., \& Kozaitis, S. P. (2014). Metric for the fusion of synthetic and real imagery from multimodal sensors. American Journal of Engineering and Applied Sciences, 355. https://doi.org/10.3844/ajeassp.2014.355.362

Nandhakumar, S., Selladurai, V., \& Sekar, S. (2009). Numerical investigation of an industrial robot arm control problem using haar wavelet series. American Journal of Engineering and Applied Sciences, 2(4). https://doi.org/10.3844/ajeassp.2009.584.589

Ng, K. C., Yusoff, M. Z., Munisamy, K., Hasini, H., \& Shuaib, N. H. (2008). Time-marching method for computations of high-speed compressible flow on structured and unstructured grid. American Journal Engineering Applied Sciences, 1(2), 89-94. https://doi.org/10.3844/ajeassp.2008.89.94

Obaiys, S. J., Abbas, Z., Long, N. N., Ahmad, A. F., Ahmedov, A., \& Raad, H. K. (2016). On the general solution of first-kind hypersingular integral equations. American Journal Engineering Applied Sciences, 9, 195-201. https://doi.org/10.3844/ajeassp.2016.195.201 
Odeh, S., Faqeh, R., Eid, L. A., \& Shamasneh, N. (2009). Vision-based obstacle avoidance of mobile robot using quantized spatial model. American Journal Engineering Applied Sciences, 2, 611-619. https://doi.org/10.3844/ajeassp.2009.611.619

Opafunso, Z. O., Ozigis, I. I., \& Adetunde, I. A. (2009). Pneumatic and hydraulic systems in coal fluidized bed combustor. American Journal Engineering Applied Sciences, 2, 88-95.

https://doi.org/10.3844/ajeassp.2009.88.95

Orlando, N., \& Benvenuti, E. (2016). Advanced XFEM simulation of pull-out and debonding of steel bars and FRP-reinforcements in concrete beams. American Journal Engineering Applied Sciences, 9, 746-754. https://doi.org/10.3844/ajeassp.2016.746.754

Pannirselvam, N., Raghunath, P. N., \& Suguna, K. (2008). Neural network for performance of glass fibre reinforced polymer plated RC beams. American Journal Engineering Applied Sciences, 1(1), 82-88. https://doi.org/10.3844/ajeassp.2008.82.88

Pattanasethanon, S. (2010). The solar tracking system by using digital solar position sensor. American Journal of Engineering and Applied Sciences, 3(4), 678-682. https://doi.org/10.3844/ajeassp.2010.678.682

Pérez-de León, G., Lamberti, V. E., Seals, R. D., AbuLebdeh, T. M., \& Hamoush, S. A. (2016). Gas atomization of molten metal: Part I. Numerical modeling conception. American Journal of Engineering and Applied Sciences, 9(2). https://doi.org/10.3844/ajeassp.2016.303.322

Petrescu, F. I. (2015a). Geometrical synthesis of the distribution mechanisms. American Journal of Engineering and Applied Sciences, 8(1), 63-81. https://doi.org/10.3844/ajeassp.2015.63.81

Petrescu, F. I. T. (2015b). Machine motion equations at the internal combustion heat engines. American Journal of Engineering and Applied Sciences, 8(1), 127. https://doi.org/10.3844/ajeassp.2015.127.137

Petrescu, F. I. (2020). Proper Management of Planetary Hydrocarbon Resources. https://doi.org/10.2139/ssrn.3609509

Petrescu, F. I. T. (2018). About the nuclear particles' structure and dimensions. Computational Particle Mechanics, 6(2), 191-194. https://doi.org/10.1007/s40571-018-0206-7

Petrescu, F. I., \& Petrescu, R. V. (2014a). Parallel moving mechanical systems. Independent Journal of Management \& Production (IJM\&P), 5(3). https://doi.org/10.14807/ijmp.v5i3.159

Petrescu, F. I., \& Petrescu, R. V. (2014b). Cam gears dynamics in the classic distribution. Independent Journal of Management \& Production (IJM\&P), 5(1). https://doi.org/10.14807/ijmp.v5i1.133
Petrescu, F. I., \& Petrescu, R. V. (2014c). High efficiency gears synthesis by avoid the interferences. Independent Journal of Management \& Production (IJM\&P), 5(2). https://doi.org/10.14807/ijmp.v5i2.147

Petrescu, F. I., \& Petrescu, R. V. (2014d). Gear design. https://doi.org/10.22409/engevista.v16i4.557

Petrescu, F. I., \& Petrescu, R. V. (2014e). KINETOSTATIC OF THE 3R DYAD. Engevista, 16(3), 314-321. https://doi.org/10.22409/engevista.v16i3.486

Petrescu, F. I. T., \& Petrescu, R. V. (2014f). Balancing otto engines. International Revise Machine Engineering, 8, 473-480.

Petrescu, F. I. T., \& Petrescu, R. V. (2014g). Machine equations to the classical distribution. International Revise Machine Engineering, 8, 309-316.

Petrescu, F. I., \& Petrescu, R. V. (2013). Dynamic synthesis of the rotary cam and translated tappet with roll. Engevista, 15(3). https://doi.org/10.22409/engevista.v15i3.491

Petrescu, F. I., \& Petrescu, R. V. (2015a). Forces at the main mechanism of a railbound forging manipulator. Independent Journal of Management \& Production, 6(4). https://doi.org/10.14807/ijmp.v6i4.316

Petrescu, F. I., \& Petrescu, R. V. (2015b). Kinematics at the main mechanism of a railbound forging manipulator. Independent Journal of Management \& Production, 6(3). https://doi.org/10.14807/ijmp.v6i3.235

Petrescu, F. I. T., \& Petrescu, R. V. V. (2015c). Machine motion equations. Independent Journal of Management \& Production, 6(3), 773-802. https://doi.org/10.14807/ijmp.v6i3.318

Petrescu, F. I., \& Petrescu, R. V. (2015d). Presenting a railbound forging manipulator. In Applied Mechanics and Materials (Vol. 762, pp. 219-224). Trans Tech Publications Ltd. https://doi.org/10.4028/www.scientific.net/AMM. 762.219

Petrescu, F. I., \& Petrescu, R. V. (2015e). Direct and inverse kinematics to the anthropomorphic robots. https://doi.org/10.22409/engevista.v18i1.729

Petrescu, F. I., \& Calautit, J. K. (2016a). About nano fusion and dynamic fusion. American Journal of Applied Sciences, 13(3). https://doi.org/10.3844/ajassp.2016.261.266

Petrescu, F. I., \& Calautit, J. K. (2016b). About the light dimensions. American Journal of Applied Sciences, 13(3). https://doi.org/10.3844/ajassp.2016.321.325

Petrescu, F. I., \& Petrescu, R. V. (2005a). The cam design for a better efficiency. https://doi.org/10.2139/ssrn.3076805

Petrescu, F. I., \& Petrescu, R. V. (2005b). Determining the dynamic efficiency of cams. https://doi.org/10.2139/ssrn.3076802 
Petrescu, F. I., \& Petrescu, R. V. (2005c). An original internal combustion engine. In The Ninth IFTOMM International Symposium on Theory of Machines and Mechanisms.

Petrescu, R. V., \& Petrescu, F. I. (2005d). Determining the mechanical efficiency of Otto engine's mechanism. https://doi.org/10.2139/ssrn.3076804

Petrescu, F. I., \& Petrescu, R. V. (2016). An otto engine dynamic model. Independent Journal of Management \& Production (IJM\&P), $7(1)$. https://doi.org/10.14807/ijmp.v7i1.381

Petrescu, F. I., Apicella, A., Petrescu, R. V., Kozaitis, S., Bucinell, R., Aversa, R., \& Abu-Lebdeh, T. (2016). Environmental protection through nuclear energy. American Journal of Applied Sciences, 13(9), 941946. https://doi.org/10.3844/ajassp.2016.941.946

Petrescu, R. V., Aversa, R., Akash, B., Berto, F., Apicella, A., \& Petrescu, F. I. (2017a). Forces of a 3R robot. Journal of Mechatronics and Robotics, 1(1). https://doi.org/10.3844/jmrsp.2017.1.14

Petrescu, R. V., Aversa, R., Akash, B., Berto, F., Apicella, A., \& Petrescu, F. I. (2017b). Dynamic elements at MP3R. Journal of Mechatronics and Robotics, 1(2), 24-37. https://doi.org/10.3844/jmrsp.2017.24.37

Petrescu, R. V., Aversa, R., Akash, B., Berto, F., Apicella, A., \& Petrescu, F. I. (2017c). Geometry and direct kinematics to MP3R with $4 \times 4$ operators. Journal of Mechatronics and Robotics, 1(2), 38-46. https://doi.org/10.3844/jmrsp.2017.38.46

Petrescu, R. V., Aversa, R., Apicella, A., \& Petrescu, F. I. (2018a). Total static balancing and kinetostatics of the 3R base cinematic Chain. Journal of Mechatronics and Robotics, 2(1), 1-13. https://doi.org/10.3844/jmrsp.2018.1.13

Petrescu, R. V., Aversa, R., Apicella, A., \& Petrescu, F. I. (2018b). Switching from flat to spatial motion to $3 \mathrm{R}$ mechatronic systems. Journal of Mechatronics and Robotics, 2(1), 14-22. https://doi.org/10.3844/jmrsp.2018.14.22

Petrescu, R. V., Aversa, R., Apicella, A., \& Petrescu, F. I. (2018c). The dynamics of the planar cinematic balanced chain at the plan module 3R. Journal of Mechatronics and Robotics, 2(1), 23-34. https://doi.org/10.3844/jmrsp.2018.23.34

Petrescu, R. V., Aversa, R., Apicella, A., \& Petrescu, F. I. (2018d). Dynamic kinematics of the plan balanced chain at the planar module 3R. Journal of Mechatronics and Robotics, 2(1), 35-44. https://doi.org/10.3844/jmrsp.2018.35.44

Pisello, A. L., Pignatta, G., Piselli, C., Castaldo, V. L., \& Cotana, F. (2016). Investigating the dynamic thermal behavior of building envelope in summer conditions by means of in-field continuous monitoring. American Journal Engineering Applied Sciences, 9, 505-519. https://doi.org/10.3844/ajeassp.2016.505.519
Popa, I. F., Andreescu, A. M. T., Ifrim, D., Mihalache, R., Mihai, D., \& Cican, G. (2019). Finite element modelling and performance optimization of an ion thruster depending on the nature of the propellant. CEAS Space Journal, 11(2), 115-122. https://doi.org/10.1007/s12567-018-0218-4

Pourmahmoud, N. (2008). Rarefied gas flow modeling inside rotating circular cylinder. American Journal Engineering Applied Sciences, 1(1), 62-65. https://doi.org/10.3844/ajeassp.2008.62.65

Pravettoni, M., Polo Lopez, C. S., \& Kenny, R. P. (2016). Impact of the edges of a backside diffusive reflector on the external quantum efficiency of luminescent solar concentrators: Experimental and computational approach. American Journal of Engineering and Applied Sciences, 9(1), 53-63. https://doi.org/10.3844/ajeassp.2016.53.63

Qutbodin, K. (2010). Merging autopilot/flight control and navigation-flight management systems. American Journal Engineering Applied Sciences, 3, 629-630. https://doi.org/10.3844/ajeassp.2010.629.630

Rajbhandari, S., Ghassemlooy, Z., \& Angelova, M. (2011). The performance of a dual header pulse position modulation in the presence of artificial light interferences in an indoor optical wireless communications channel with wavelet denoising. American Journal of Engineering and Applied Sciences, 4(4), 513-519. https://doi.org/10.3844/ajeassp.2011.513.519

Rajput, R. S., Pandey, S., \& Bhadauria, S. (2016). Correlation of biodiversity of algal genera with special reference to the waste water effluents from industries. American Journal Engineering Applied Sciences, 9, 1127-1133. https://doi.org/10.3844/ajeassp.2016.1127.1133

Rama, G., Marinković, D., \& Zehn, M. (2016). Efficient co-rotational 3-node shell element. American Journal of Engineering and Applied Sciences. https://doi.org/10.3844/ajeassp.2016.902.912

Raptis, K. G., Papadopoulos, G. A., Costopoulos, T. N., \& Tsolakis, A. D. (2011). Experimental study of load sharing in roller-bearing contact by caustics and photoelasticity. American Journal Engineering Applied Sciences, 4, 294-300. https://doi.org/10.3844/ajeassp.2011.294.300

Rea, P., \& Ottaviano, E. (2016). Analysis and mechanical design solutions for sit-to-stand assisting devices. American Journal Engineering Applied Sciences, 9, 1134-1143. https://doi.org/10.3844/ajeassp.2016.1134.1143

Riccio, A., Caruso, U., Raimondo, A., \& Sellitto, A. (2016a). Robustness of XFEM method for the simulation of cracks propagation in fracture mechanics problems. https://doi.org/10.3844/ajeassp.2016.599.610 
Riccio, A., Cristiano, R., \& Saputo, S. (2016b). A brief introduction to the bird strike numerical simulation. https://doi.org/10.3844/ajeassp.2016.946.950

Rich, F., \& Badar, M. A. (2016). Statistical analysis of auto dilution Vs manual dilution process in inductively coupled plasma spectrometer tests. American Journal Engineering Applied Sciences, 9, 611-624. https://doi.org/10.3844/ajeassp.2016.611.624

Rohit, K., \& Dixit, S. (2016). Mechanical properties of waste Biaxially Oriented Polypropylene metallized films (BOPP), LLDPE: LDPE films with sisal fibres. American Journal Engineering Applied Sciences, 9, 913-920. https://doi.org/10.3844/ajeassp.2016.913.920

Rulkov, N. F., Hunt, A. M., Rulkov, P. N., \& Maksimov, A. G. (2016). Quantization of map-based neuronal model for embedded simulations of neurobiological networks in real-time. American Journal of Engineering and Applied Sciences, 9(4), 973-984. https://doi.org/10.3844/ajeassp.2016.973.984

Saikia, A., \& Karak, N. (2016). Castor oil based epoxy/clay nanocomposite for advanced applications. American Journal Engineering Applied Sciences, 9, 31-40. https://doi.org/10.3844/ajeassp.2016.31.40

Sallami, A., Zanzouri, N., \& Ksouri, M. (2016). Robust diagnosis of a DC motor by bond graph approach. American Journal Engineering Applied Sciences, 9, 432-438. https://doi.org/10.3844/ajeassp.2016.432.438

Samantaray, K. S., Sahoo, S., \& Rout, C. S. (2016). Hydrothermal synthesis of CuWO4-reduced graphene oxide hybrids and supercapacitor application. American Journal Engineering Applied Sciences, 9, 584-590 https://doi.org/10.3844/ajeassp.2016.584.590

Sandu, C., Silivestru, V., Cican, G., Șerbescu, H., Tipa, T., Totu, A., \& Radu, A. (2020). On a New Type of Combined Solar-Thermal/Cold Gas Propulsion System Used for LEO Satellite's Attitude Control. Applied Sciences, 10(20), 7197. https://doi.org/10.3390/app10207197

Semin, S., Ismail, A. R., \& Bakar, R. A. (2009a). Combustion temperature effect of diesel engine convert to compressed natural gas engine. American Journal of Engineering and Applied Sciences, 2(1). https://doi.org/10.3844/ajeassp.2009.212.216

Semin, Ismail, A. R., \& Rosli, A. B. (2009b). Effect of diesel engine converted to sequential port injection compressed natural gas engine on the cylinder pressure vs crank angle in variation engine speeds. American Journal Engineering Applied Sciences, 2(1), 154-9. https://doi.org/10.3844/ajeas.2009.154.159

Semin, S., Ismail, A. R., \& Bakar, R. A. (2009c). Diesel engine convert to port injection $\mathrm{CNG}$ engine using gaseous injector nozzle multi holes geometries improvement: A review. American Journal of Engineering and Applied Sciences, 2(2). https://doi.org/10.3844/ajeassp.2009.268.278
Semin, R. A. B. (2008). A technical review of compressed natural gas as an alternative fuel for internal combustion engines. American Journal Engineering Applied Sciences, 1(4), 302-311. https://doi.org/10.3844/ajeassp.2008.302.311

Sepúlveda, J. A. M. (2016). Outlook of municipal solid waste in Bogota (Colombia). American Journal Engineering Applied Sciences, 9, 477-483. https://doi.org/10.3844/ajeassp.2016.477.483

Serebrennikov, A., Serebrennikov, D., \& Hakimov, Z. (2016). Polyethylene pipeline bending stresses at an installation. American Journal Engineering Applied Sciences, 9, 350-355. https://doi.org/10.3844/ajeassp.2016.350.355

Shanmugam, K. (2016). Flow dynamic behavior of fish oil/silver nitrate solution in mini-channel, effect of alkane addition on flow pattern and interfacial tension. American Journal Engineering Applied Sciences, 9, 236-250. https://doi.org/10.3844/ajeassp.2016.236.250

Shruti, (2016). Comparison in cover media under stegnography: Digital media by hide and seek approach. American Journal Engineering Applied Sciences, 9, 297-302. https://doi.org/10.3844/ajeassp.2016.297.302

Suarez, L., Abu-Lebdeh, T. M., Picornell, M., \& Hamoush, S. A. (2016). Investigating the role of fly ash and silica fume in the cement hydration process. American Journal Engineering Applied Sciences, 9, 134-145. https://doi.org/10.3844/ajeassp.2016.134.145

Syahrullah, L. O. I., \& SINAGA, N. (2016). Optimization and prediction of motorcycle injection system performance with feed-forward back-propagation method Artificial Neural Network (ANN). American Journal of Engineering and Applied Science, 9(2), 222235. https://doi.org/10.3844/ajeassp.2016.222.235

Taher, S. A., Hematti, R., \& Nemati, M. (2008). Comparison of different control strategies in GA-based optimized UPFC controller in electric power systems. American Journal Engineering Applied Sciences, 1(1), 45-52. https://doi.org/10.3844/ajeassp.2008.45.52

Theansuwan, W., Sriprateep, K., \& Palaprom, A. (2011, July). The biodiesel production from roast Thai sausage oil by transesterification reaction. In ITC-CSCC: International Technical Conference on Circuits Systems, Computers and Communications (pp. 1-4). https://doi.org/10.3844/ajeassp.2011.130.132

Thongwan, T., Kangrang, A., \& Homwuttiwong, S. (2011). An estimation of rainfall using fuzzy setgenetic algorithms model. American Journal Engineering Applied Sciences, 4, 77-81. https://doi.org/10.3844/ajeassp.2011.77.81

Tourab, W., Babouri, A., \& Nemamcha, M. (2011). Experimental study of electromagnetic environment in the vicinity of high voltage lines. American Journal Engineering Applied Sciences, 4, 209-213. https://doi.org/10.3844/ajeassp.2011.209.213 
Tsolakis, A. D., \& Raptis, K. G. (2011). Comparison of maximum gear-tooth operating bending stresses derived from niemann's analytical procedure and the finite element method. American Journal Engineering Applied Sciences, 4, 350-354. https://doi.org/10.3844/ajeassp.2011.350.354

Wang, J., \& Yagi, Y. (2016). Fragment-based visual tracking with multiple representations. American Journal Engineering Applied Sciences, 9, 187-194. https://doi.org/10.3844/ajeassp.2016.187.194

Wang, L., Liu, T., Zhang, Y., \& Yuan, X. (2016). A methodology for continuous evaluation of cloud resiliency. American Journal Engineering Applied Sciences, 9, 264-273. https://doi.org/10.3844/ajeassp.2016.264.273

Waters, C., Ajinola, S., \& Salih, M. (2016). Dissolution sintering technique to create porous copper with sodium chloride using polyvinyl alcohol solution through powder metallurgy. American Journal Engineering Applied Sciences, 9, 155-165. https://doi.org/10.3844/ajeassp.2016.155.165

Wessels, L., \& Raad, H. (2016). Recent advances in point of care diagnostic tools: A review. American Journal Engineering Applied Sciences, 9, 1088-1095. https://doi.org/10.3844/ajeassp.2016.1088.1095

Yeargin, R., Ramey, R., \& Waters, C. (2016). Porosity analysis in porous brass using dual approaches. American Journal Engineering Applied Sciences, 9, 91-97. https://doi.org/10.3844/ajeassp.2016.91.97

You, M., Huang, X., Lin, M., Tong, Q., \& Li, X. (2016). Preparation of $\mathrm{LiCoMnO} 4$ assisted by hydrothermal approach and its electrochemical performance. American Journal Engineering Applied Sciences, 9, 396-405. https://doi.org/10.3844/ajeassp.2016.396.405

Zeferino, R. S., Ramón, J. R., de Anda Reyes, E., Gónzalez, R. S., \& Pal, U. (2016). Large scale synthesis of $\mathrm{ZnO}$ nanostructures of different morphologies through solvent-free mechanochemical synthesis and their application in photocatalytic dye degradation. American Journal Engineering Applied Sciences, 9, 41-52. https://doi.org/10.3844/ajeassp.2016.41.52
Zhao, B. (2013). Identification of multi-cracks in the gate rotor shaft based on the wavelet finite element method. American Journal Engineering Applied Sciences, 6, 309-319. https://doi.org/10.3844/ajeassp.2013.309.319

Zheng, H., \& Li, S. (2016). Fast and robust maximum power point tracking for solar photovoltaic systems. American Journal Engineering Applied Sciences, 9, 755-769. https://doi.org/10.3844/ajeassp.2016.755.769

Zotos, I. S., \& Costopoulos, T. N. (2009). On the use of rolling element bearings' models in precision maintenance. American Journal Engineering Applied Sciences, 2, 344-352. https://doi.org/10.3844/ajeassp.2009.344.352

Zulkifli, R., Sopian, K., Abdullah, S., \& Takriff, M. S. (2008). Effect of pulsating circular hot air jet frequencies on local and average nusselt number. American Journal of Engineering and Applied Sciences, 1(1), 57-61. https://doi.org/10.3844/ajeassp.2008.57.61

Zulkifli, R., Sopian, K., Abdullah, S., \& Takriff, M. S. (2009). Experimental study of flow structures of circular pulsating air jet. American Journal of Engineering and Applied Sciences, 2(1). https://doi.org/10.3844/ajeas.2009.171.175

Zurfi, A., \& Zhang, J. (2016a). Model identification and wall-plug efficiency measurement of white LED modules. American Journal Engineering Applied Sciences, 9, 412-419. https://doi.org/10.3844/ajeassp.2016.412.419

Zurfi, A., \& Zhang, J. (2016b). Exploitation of battery energy storage in load frequency control-a literature survey. American Journal Engineering Applied Sciences, 9, 1173-1188. https://doi.org/10.3844/ajeassp.2016.1173.1188 